\title{
Observations of high droplet number concentrations in Southern Ocean boundary layer clouds
}

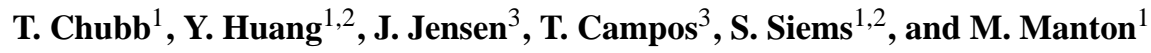 \\ ${ }^{1}$ School of Earth, Atmosphere and Environment, Monash University, Melbourne, \\ VIC 3800, Australia \\ ${ }^{2}$ Australian Research Council (ARC) Centre of Excellence for Climate System Science, \\ Monash University, Melbourne, VIC 3800, Australia \\ ${ }^{3}$ NCAR Research Aviation Facility, 10802 Airport Court Rocky Mountain Metropolitan \\ Airport, Broomfield, CO 80021, USA \\ Correspondence to: T. Chubb (thomas.chubb@gmail.com)
}

Received: 31 August 2015 - Published in Atmos. Chem. Phys. Discuss.: 17 September 2015

Revised: 21 December 2015 - Accepted: 28 December 2015 - Published: 27 January 2016

\begin{abstract}
Cloud physics data collected during the NSF/NCAR High-performance Instrumented Airborne Platform for Environmental Research (HIAPER) Pole-toPole Observations (HIPPO) campaigns provide a snapshot of unusual wintertime microphysical conditions in the boundary layer over the Southern Ocean. On 29 June 2011, the HIAPER sampled the boundary layer in a region of prefrontal warm air advection between 58 and $48^{\circ} \mathrm{S}$ to the south of Tasmania. Cloud droplet number concentrations were consistent with climatological values in the northernmost profiles but were exceptionally high for wintertime in the Southern Ocean at $100-200 \mathrm{~cm}^{-3}$ in the southernmost profiles. Sub-micron $(0.06<D<1 \mu \mathrm{m})$ aerosol concentrations for the southern profiles were up to $400 \mathrm{~cm}^{-3}$.

Analysis of back trajectories and atmospheric chemistry observations revealed that while conditions in the troposphere were more typical of a clean remote ocean airmass, there was some evidence of continental or anthropogenic influence. However, the hypothesis of long-range transport of continental aerosol fails to explain the magnitude of the aerosol and cloud droplet concentration in the boundary layer. Instead, the gale force surface winds in this case (wind speed at $167 \mathrm{~m}$ above sea level was $>25 \mathrm{~m} \mathrm{~s}^{-1}$ ) were most likely responsible for production of sea spray aerosol which influenced the microphysical properties of the boundary layer clouds. The smaller size and higher number concentration of cloud droplets is inferred to increase the albedo of these clouds, and these conditions occur regularly, and are
\end{abstract}

expected to increase in frequency, over windy parts of the Southern Ocean.

\section{Introduction}

The remote Southern Ocean ( $\mathrm{SO}$; poleward of $45^{\circ} \mathrm{S}$ ) has recently received attention due to substantial biases in both reanalysis and climate simulations associated with clouds (Meehl et al., 2007; Trenberth and Fasullo, 2010). In this pristine environment, cloud properties may be sensitive to relatively small changes in aerosol concentrations, whether from anthropogenic or natural sources, but there has been a distinct lack of in situ microphysical observational campaigns in this region in recent years. High-latitude oceanatmosphere interactions and processes have been identified as a key research frontier by the NSF Advisory Committee for Geosciences (2014).

The pristine environment of the SO raised questions about cloud droplet number concentration $\left(N_{\mathrm{C}}\right)$ and droplet sizes observed there in the early 1990s. Boers et al. (1996), Boers and Krummel (1998), and Boers et al. (1998) considered $N_{\mathrm{C}}$ within, and cloud condensation nuclei (CCN) concentrations below, SO boundary layer clouds in "baseline" conditions (with an airmass history far from continental Australia) during the First Aerosol Characterization Experiment (ACE-I, November to December 1995) and the two phases of the Southern Ocean Cloud Experiment (SOCEX- 
I, July 1993; SOCEX-II, February 1995). In wintertime, $N_{\mathrm{C}}$ was found to be low, at typically $10-40 \mathrm{~cm}^{-3}$ for clouds of up to $300 \mathrm{~m}$ deep, compared to summertime values of 50 $180 \mathrm{~cm}^{-3}$. A caveat with the lowest wintertime $N_{\mathrm{C}}$ values of that study is that they were highly correlated with the cloud liquid water content, suggesting that clear air may have been mixed into those samples.

Seasonal differences in $N_{\mathrm{C}}$ during the SOCEX experiments were attributed to oxidation products of oceanic dimethylsulphide (DMS) acting as CCN, due to seasonal variation in the productivity of the ocean (Boers et al., 1998). At the time it was widely hypothesized that DMS-derived particulates made up the bulk of all sub-micrometer particles (Charlson et al., 1987), which linked ocean productivity to cloud albedo and thus global climate through the so-called "CLAW" hypothesis. However, a review of 2 decades of subsequent research suggested that the evidence for each of the stages in this mechanism was rather weak (Quinn and Bates, 2011), and that sea spray aerosol (SSA) comprises a substantial fraction of the marine boundary layer $\mathrm{CCN}$ concentration.

The HIAPER Pole-to-Pole Observations flights (HIPPO; Wofsy, 2011) were not dedicated cloud physics experiments but have nevertheless provided some new data at high latitudes over the SO. Chubb et al. (2013) examined two SO flights that encountered low-altitude cloud (i.e. below $2 \mathrm{~km}$ ) as far south as $67^{\circ} \mathrm{S}$. Direct $N_{\mathrm{C}}$ observations were only available on one of those flights, which took place in the month of April, and ranged from 30 to $50 \mathrm{~cm}^{-3}$ in weakly convective stratocumulus cloud in the cold air sector of an extratropical cyclone at latitudes around $59^{\circ} \mathrm{S}$, to $80-120 \mathrm{~cm}^{-3}$ in a region of homogeneous stratiform cloud in moderate south-westerly flow between $62-67^{\circ} \mathrm{S}$. Broadly speaking, these values were in line with those from ACE-I and the SOCEX experiments.

Cloud particle effective radius $r_{\mathrm{e}}$ and optical thickness $\tau$ are standard retrievals (e.g. Nakajima and King, 1990) that may be performed with radiance data from the Moderate Resolution Imaging Spectroradiometer (MODIS; Salomonson et al., 1989). Bennartz (2007) used 2 and a half years of Aqua MODIS retrievals to calculate $N_{\mathrm{C}}$ over remote oceanic regions. $N_{\mathrm{C}}$ values for the Southern Hemisphere oceans (equatorward of $60^{\circ} \mathrm{S}$ ) were $40-67 \mathrm{~cm}^{-3}$, compared to $64-89 \mathrm{~cm}^{-3}$ for the Northern Hemisphere. The estimated frequency of drizzle (based on empirical relationships with $N_{\mathrm{C}}$ and cloud geometric thickness) was substantially higher in the Southern Hemisphere oceans. A limitation in the use of these retrievals at high latitudes, which was not considered by Bennartz (2007), is the solar angle, which must be greater than about $65^{\circ}$ to be reliable (Grosvenor and Wood, 2014). In wintertime, it is virtually impossible to perform robust $r_{\mathrm{e}}$ retrievals over the SO.

The primary mechanism of SSA production is the bursting of small bubbles at the sea surface within breaking wave crests, or whitecaps (Day, 1964). The "film drop" particles produced are typically in the radius range of $0.01-1 \mu \mathrm{m}$, re- main suspended for long periods, and form the dominant contribution to marine SSA number concentration (Lewis and Schwartz, 2004, ch. 4). Larger particles can be formed in lower concentrations by "jet" and "spume" mechanisms, but these tend to fall to the sea surface on timescales of seconds to hours and may not contribute substantially to $\mathrm{CCN}$ number concentrations.

In spite of the intuitive link between wind speed and SSA concentration, which has long been recognized (Woodcock, 1953), the case for a formulation based on wind speed alone is mixed. SSA production flux per whitecap area is typically assumed to be independent of wind speed, permitting estimates based on fractional whitecap area $(W)$. However, $W$ can vary by an order of magnitude for the same wind speed (Lewis and Schwartz, 2004, ch. 3), and the underlying uncertainties in the production fluxes are large (de Leeuw et al., 2011). In spite of this, a relationship between the logarithm of SSA concentration $\left(N_{\mathrm{SSA}}\right)$ and the local wind speed is typically assumed. Several studies (e.g. Marks, 1990; O'Dowd and Smith, 1993; Nilsson et al., 2001) report very good agreement with this formulation, but during ACE-I, other investigators have reported little or no correlation of $N_{\mathrm{SSA}}$ with wind speed (Bates et al., 1998; Covert et al., 1998; Berg et al., 1998). More recently, (Blot et al., 2013) presented observations of $N_{\text {SSA }}$ made in the unpolluted south-eastern Pacific during the VOCALS (Variability of the American Monsoon Systems (VAMOS) Ocean-Cloud-Atmosphere-Land Study) campaign. These data, recorded over a range of $1000 \mathrm{~km}$ along the $20^{\circ} \mathrm{S}$ meridian, showed only a weak relationship to wind speeds up to about $12 \mathrm{~m} \mathrm{~s}^{-1}$. The authors concluded that other factors, especially local precipitation history, may play an important role in determining SSA concentrations.

High aerosol concentrations over the SO (an important topic for this paper) could also be caused by long-range transport of aerosol from the Australian continent. Using back trajectory analysis coupled with radon and condensation nuclei (CN) concentration observations, Downey et al. (1990) found that long-range transport could explain up to $25 \%$ of the variance of radon concentration, which is a good proxy for "land contact", at Macquarie Island $\left(54.62^{\circ} \mathrm{S}, 158.85^{\circ} \mathrm{E}\right)$. $\mathrm{CN}$ concentrations reached values above $1000 \mathrm{~cm}^{-3}$ for short intervals while trajectories were of continental origin, but the trajectory statistics used ("hours of land contact" and "time since land contact") showed very poor, and even negative, correlation to $\mathrm{CN}$ concentrations. This was attributed to nonuniformity of $\mathrm{CN}$ sources on the continent and processes acting as sinks and sources over the ocean (neither of which affect radon concentration).

This paper focuses on some observations from a single flight over the SO in winter during the 4th HIPPO campaign (HIPPO-4). Cloud droplet and aerosol concentrations were considerably higher than expected in a region that was more than $1500 \mathrm{~km}$ from the nearest potential pollution sources. The main hypothesis addressed by this paper is that these observations can be attributed to high SSA production due to 
very strong low-level winds associated with the approach of a strong cold front. Direct evidence for this hypothesis (in the form of observations of aerosol composition) is not available, so our objectives are firstly to verify and analyze the available in-flight microphysics observations, and secondly to investigate the alternative hypothesis that long-range transport of continental and/or anthropogenic aerosols influenced microphysical conditions.

\section{Methodology and data}

With the primary objective of conducting a global survey of climatically important aerosols and trace gases, the NSF/NCAR HIAPER (a high-performance research aircraft based on a Gulfstream-V jet), conducted five global transects in different seasons between 2009 and 2011 for the HIPPO campaigns (Wofsy, 2011).

The primary data set used to perform the analyses in this paper was the "Low Rate $(1 \mathrm{~Hz})$ Navigation, State Parameter and Microphysics Flight-Level Data" product (Romashkin, 2012) prepared by the NCAR Research Aviation Facility (RAF). In addition, we used 1-s data from additional instrumentation, which were processed by various HIPPO investigators separately from the flight-level data (see below). These data formed the basis for the medianfiltered "Merged 10 s Meteorology, Atmospheric Chemistry, and Aerosol Data" product (Wofsy et al., 2012), which has been used in many of the publications resulting from the HIPPO campaigns.

\subsection{Flight overview}

During daylight hours of 28-29 June 2011 (solar time), the HIAPER flew from Christchurch (New Zealand), to Hobart (Australia) via a way-point at $58^{\circ} \mathrm{S}$, due south of Hobart. The mean sea level pressure (MSLP) analysis for 00:00 UTC 29 June 2011 (Fig. 1) shows a remarkably strong blocking anticyclone with a high-pressure center of $1042 \mathrm{hPa}$ over the Tasman Sea. A mature, decaying frontal system was approaching from the west, with a secondary wave anomaly located at about $48^{\circ} \mathrm{S}, 130^{\circ} \mathrm{E}$. This synoptic pattern generated a strong south-westerly pressure gradient in the pre-frontal airmass, with ERA-Interim wind speeds at $950 \mathrm{hPa}$ in excess of $20 \mathrm{~m} \mathrm{~s}^{-1}$ associated with strong poleward warm air advection.

The Aqua satellite passed overhead at 03:45 UTC, while the HIAPER was mid-flight. MODIS retrievals show widespread boundary layer clouds with cloud top temperature (CTT) of 270 to $280 \mathrm{~K}$ underneath the blocking high (Fig. 2). A complex of multilayer clouds, with CTT in the range of 220-240 K, resided in the pre-frontal stream overlying the boundary layer cloud. In the vicinity of the secondary wave anomaly, the high level cloud band was broken, permitting retrievals of the boundary layer cloud beneath, which

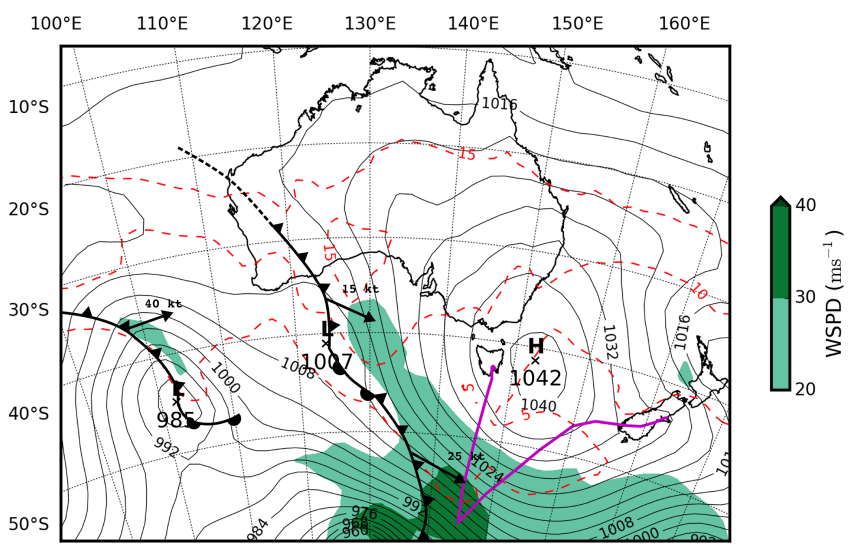

Figure 1. ERA-Interim mean sea level pressure at 00:00 UTC on 29 June 2011, with synoptic features as analyzed by the Australian Bureau of Meteorology, $950 \mathrm{hPa}$ wind speed (colors; $\mathrm{ms}^{-1}$ ), and $950 \mathrm{hPa}$ temperatures (dashed red contours at 5,10 , and $15^{\circ} \mathrm{C}$ ). The flight track for HIPPO-4 RF06 is shown in magenta.

appeared to be consistent with the cloud well ahead of the frontal band.

The aircraft performed four descent/ascent profiles between 9000 and $160 \mathrm{~m}$ above sea level (a.s.l.) while in transit from the southernmost point to Hobart, which we discuss in reverse order (north to south) below. The locations of the short low-level legs (at about 160 ma.s.l.) between the descent and ascent profiles are shown in Fig. 2, and imagery from the forward facing camera showing cloud top conditions are provided in Fig. 3. The mean true air speed varied during the profiles, but it was consistently about $130 \mathrm{~m} \mathrm{~s}^{-1}$ at altitudes below $1500 \mathrm{~m}$ a.s.l. (well above the boundary layer). The vertical speed of the HIAPER was about $7.5 \mathrm{~m} \mathrm{~s}^{-1}$ for altitudes above $600 \mathrm{~m}$ a.s.1., and $2.5 \mathrm{~m} \mathrm{~s}^{-1}$ below this. A total distance of about $38 \mathrm{~km}$ was covered between the lowest level and $1500 \mathrm{~m}$ a.s.l. for each profile. Conditions were quite varied between the profiles, with profiles 3 and 4 occurring close to the location of the synoptic front, and profiles 1 and 2 in pre-frontal conditions. In all but profile 1, there was some cirrus cloud well above the maximum altitude reached in the profiles.

\subsection{HIPPO basic cloud physics instrumentation}

Basic cloud microphysics instruments were operated in addition to the primary payload instrumentation, including:

- Particle Measurement Systems (PMS) 2-D Cloud Imaging Probe $(2 D C)$. Precipitation particles larger than about $50 \mu \mathrm{m}$ can be imaged by optical array probes such as the 2DC. The instrument returns particle statistics in the form of a size distribution histogram with 64 bins between 12.5 and $1600 \mu \mathrm{m}$ as well as individual particle images. This type of probe is susceptible to uncertainties in depth-of-field for particles with diameters less 


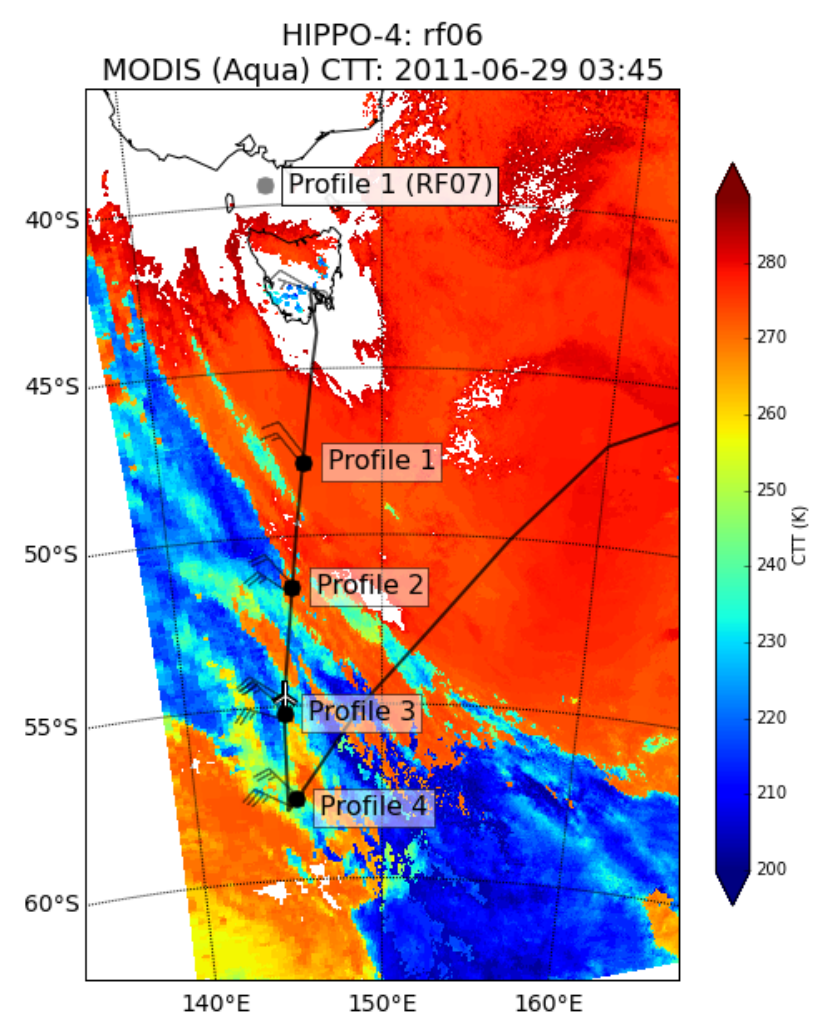

Figure 2. Flight track for HIPPO-4 RF06, with MODIS cloud top temperature overlay. The locations of the lowest level of the four profiles are labeled as per the text.

than $200 \mu \mathrm{m}$ (Baumgardner and Korolev, 1997), but we made no specific correction for this other than only using particles with diameters larger than $62.5 \mu \mathrm{m}$ to determine drizzle drop number concentrations and rain rates (no ice was observed in the boundary layer clouds).

- Droplet Measurement Technologies (DMT) Cloud Droplet Probe (CDP). The CDP operates by illuminating individual droplets with a laser beam and measuring the intensity of the forward-scattered light over angles between 4 and $12^{\circ}$ (Lance et al., 2010), and sizes them with a multi-channel analyzer. The instrument returns a particle size distribution over 30 bins between 2.0 and $50 \mu \mathrm{m}$ at $1 \mathrm{~Hz}$. Droplet number concentration $\left(N_{\mathrm{C}}\right)$ and liquid water content $\left(\rho_{\mathrm{L}} ; \mathrm{g} \mathrm{m}^{-3}\right)$ are subsequently derived from the size distribution. The CDP sizing was calibrated using glass beads of known sizes in Boulder, $\mathrm{CO}$, prior to the commencement of HIPPO-4. Subsequently to the HIPPO missions, the CDP had its true sample area evaluated through a laboratory beam mapping by the manufacturer in June 2015. We recalculated $\rho_{\mathrm{L}}$ and $N_{\mathrm{C}}$ using the updated sample area. Further discussion of the uncertainties associated with this instrument is provided in Sect. 5.1.
- DMT Ultra High Sensitivity Aerosol Spectrometer (UH$S A S)$. The UHSAS measures sizes of aerosol particles between 60 and $1000 \mathrm{~nm}$ based on light scattering (Cai et al., 2008). Due to the combined effect of electrical anti-ice and internal heating, and adiabatic heating of decelerated inlet air, we assumed that the measured particle diameters were close to their dry diameters (e.g. Blot et al., 2013; Kassianov et al., 2015). We designate the total particle concentration measured by the UHSAS as $N_{\mathrm{U}}$ in this paper. The instrument was calibrated using polystyrene latex beads of known sizes prior to HIPPO-4.

- PMS-King "hot-wire" probe. Total cloud liquid water content can be directly measured by exposing a temperature-controlled element to the flow outside the aircraft (King et al., 1978). Within cloud, the power required to maintain a constant temperature is compared to that required in clear air to derive $\rho_{\mathrm{L}, \text { King }}$.

Additionally, there are a number of basic thermodynamic and inertial observations used in this paper, and real-time forward digital camera imagery was available.

We partitioned the data by liquid water content, using $\rho_{\mathrm{L}}<0.01 \mathrm{gm}^{-3}$ for "probably clear" samples, needed for ensuring that the UHSAS observations were robust (see Sect. 5.2); and $\rho_{\mathrm{L}}>0.05 \mathrm{gm}^{-3}$ for "confident cloudy" samples, for calculating $N_{\mathrm{C}}$ from the CDP data. Similar thresholds are commonly used to discriminate between clear and cloudy samples (e.g. Wood and Field, 2011; Boutle et al., 2014) when high-rate data are unavailable (as in this case). Our study differs by using two thresholds to more selectively discriminate between cloudy and clear air.

\subsection{HIPPO trace gas and aerosol instrumentation}

To address the possibility that the high aerosol concentrations observed in the boundary layer are due to long-range transport of pollution from the Australian continent, we used atmospheric chemistry collected during the flight:

- DMT Single Particle Soot Photometer (SP2). The presence of black carbon (BC), or soot, indicates combustion, and is an excellent tracer for anthropogenic aerosol sources. The SP2 measures the incandescence temperature of particles illuminated by a laser beam (Schwarz et al., 2006). BC data acquired in clouds were removed from the HIPPO data set based on SP2 internal diagnostics, the 2DC and CDP, and the hot-wire liquid water sensor.

- AeroLaser Vacuum Ultra Violet (VUV) resonance fluorescence instrument. Carbon monoxide (CO) is another useful indicator of combustion, but there are also natural marine sources. The VUV operates on the principle of CO fluorescence in the $160-190 \mathrm{~nm}$ wavelength range upon excitation with ultra violet light at $150 \mathrm{~nm}$. The 

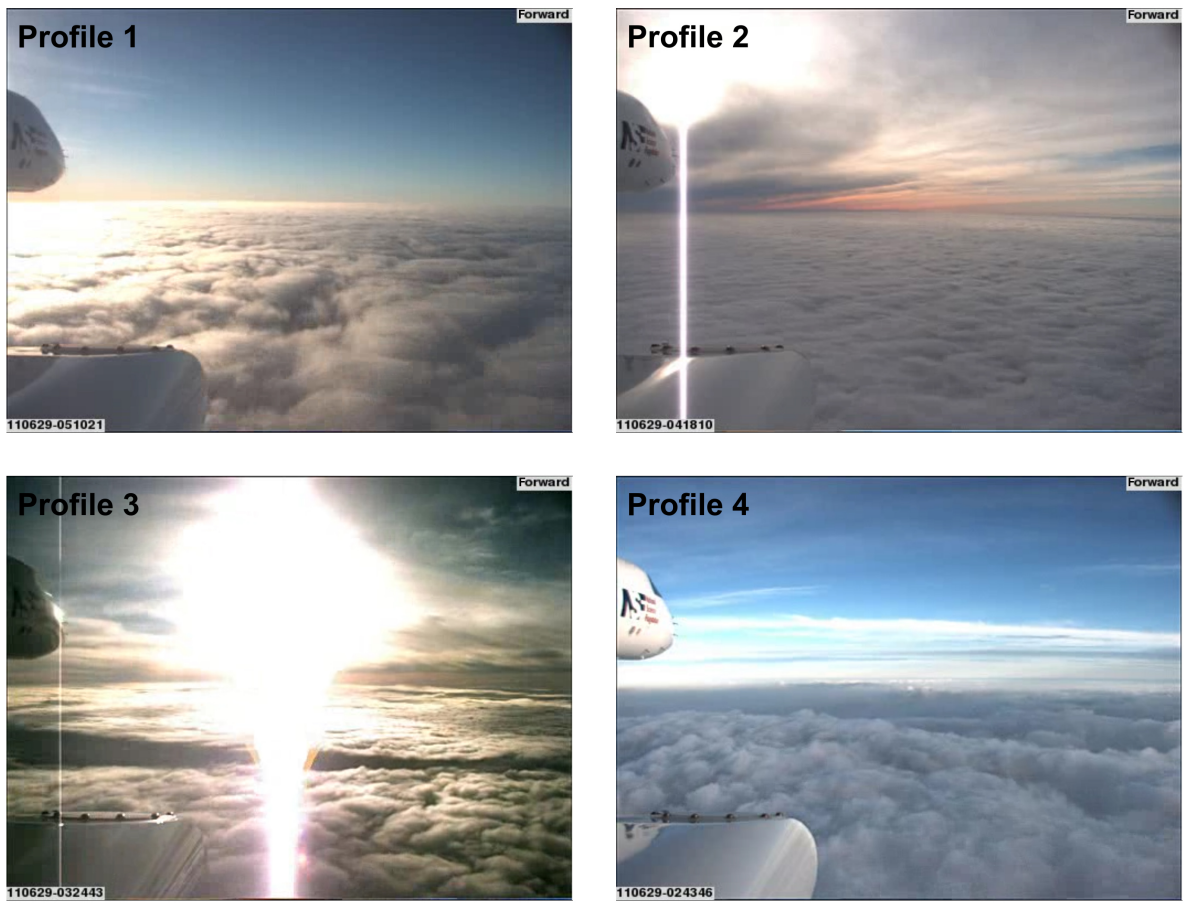

Figure 3. Forward camera imagery of boundary layer cloud top conditions for the four profiles as labeled.

technology is relatively mature and has been employed on aircraft platforms for over a decade (Gerbig et al., 1999).

Unfortunately, there was no compositional analysis of aerosols performed apart from the presence of BC. In principle, this leaves open the possibility of elevated $N_{\mathrm{U}}$ values due to continental (mineral) dust in the absence of $\mathrm{CO}$ or $\mathrm{BC}$, as anthropogenic aerosol emissions are almost exclusively produced in conjunction with combustion. We explore this possibility further in Sect. 4.4.

\subsection{Modal decomposition of UHSAS particle size distribution}

Even without information about aerosol composition, it is still possible to estimate the contribution of SSA to the observed UHSAS concentration. Modini et al. (2015) fitted lognormal modes to observed aerosol size distributions off the Californian coast. The primary marine aerosol (dominated by SSA) was isolated by fitting a lognormal mode, constrained to having $\mu$ (mean diameter) of $0.2 \mu \mathrm{m} \pm 30 \%$ (i.e. 0.14 $0.26 \mu \mathrm{m})$ and $\sigma$ (geometric standard deviation) of between 2.5 and 3. This mode was fitted to the upper portion of the PSD only $(D>0.5 \mu \mathrm{m})$, and a second unconstrained mode, corresponding to a cloud-processed accumulation mode, was fitted to the residual of the PSD following subtraction of the SSA mode. Modini et al. (2015) fitted a third mode with mean diameter of $25-80 \mathrm{~nm}$, but we have no observations of particles in that size range.
We used this approach on $60 \mathrm{~s}$ PSDs for the UHSAS at the lowest level of flight for each profile, with the size bins aggregated into groups of three to reduce noise. The only difference with our analysis was that we optimized the cut-off for the SSA mode-fitting. We chose a diameter in the range $0.2-0.5 \mu \mathrm{m}$ that minimized the root mean square error of the combined lognormal fits relative to the original PSD. This was necessary because the upper size of the UHSAS was considerably lower than the instruments used by Modini et al. (2015), and the sensitivity of the UHSAS in the larger bins is limited. The sensitivity of the results to the use of a variable threshold was indeed quite low.

\subsection{Calculation of back trajectories}

We used the Hybrid Single Particle Lagrangian Integrated Trajectory Model (HYSPLIT; Draxler and Hess, 1998) to calculate back trajectories via the Air Resources Laboratory (ARL) portal (http://www.arl.noaa.gov/HYSPLIT.php). The meteorological data selected to run the calculations were based on output from the U.S. National Weather Service's National Centers for Environmental Prediction (NCEP) Global Data Assimilation System (GDAS). The ARL processes and archives this output as a 3 hourly, global, one degree latitude-longitude data set on mandatory pressure levels ( 21 levels between 1000 and $1 \mathrm{hPa}$ ). This data set is sufficient to resolve the synoptic scale features which are dominant, at least in the free troposphere, and is available through the HYSPLIT portal. 
Draxler and Hess (1998) provide a discussion of factors influencing the accuracy of meteorological trajectories, which is worth summarizing here. The way that vertical motion is treated is especially important because horizontal wind components generally vary with height, so any vertical displacement errors will contribute to horizontal displacement errors as well. Vertical winds are generally deduced from the divergence of modeled horizontal components and can be noisy. It is possible to calculate isentropic trajectories, which follow surfaces of constant $\theta$, which is a good approximation to the motion of dry air in the free troposphere. However, this assumption is not useful in the boundary layer (which is important for this paper) where $\theta$ is well-mixed, so we used modeled vertical velocities in spite of these caveats.

Other factors that could influence the accuracy of our trajectories are that the reanalysis products over the $\mathrm{SO}$ are known to be questionable (e.g. Hande et al., 2012b; Huang et al., 2015), and that our region of interest was experiencing a rapid dynamical change with the approaching cold front. In order to test the sensitivity of the trajectory calculations of these uncertainties, we used an ensemble approach in which 26 additional trajectories were calculated in addition to the "deterministic" one. These were initialized at horizontal perturbations of $\Delta x$ and $\Delta y$ of one grid point (one degree), and $\Delta \sigma$ of 0.01 (about $250 \mathrm{~m}$ ), the standard configuration recommended by the ARL portal, and translated back to the central point.

Back trajectories ensembles were initialized along the flight path where the HIAPER was within the boundary layer cloud in profiles 1-4, at levels of 500 (within the boundary layer), 1500 (just above the boundary layer top) and at a third height between 3000 and $4500 \mathrm{~m}$ a.s.l., selected based on features of the atmospheric chemistry data. The initialization time for each location was the closest hour to the time that the HIAPER was in cloud, and the total duration of the trajectories calculated was $72 \mathrm{~h}$.

\section{Analysis of flight data}

\subsection{Basic thermodynamic observations}

Figure 4 shows thermodynamic observations from each of the descending profiles from the $1 \mathrm{~Hz}$ data set. The slantwise nature of aircraft profiles leaves open the possibility of horizontal inhomogeneity limiting the analysis, but the values for the ascending profiles were not substantially different, except that the HIAPER ascended through a cloud-free patch during profile 2. Profile 1, the northernmost and furthest ahead of the synoptic front, is a classic example of a well-mixed marine boundary layer capped with stratocumulus cloud. There was a strong virtual potential temperature $\left(\theta_{\mathrm{v}}\right)$ inversion at cloud top of about $6^{\circ} \mathrm{C}$. The height of the inversion was about $1150 \mathrm{~m}$, and the temperature at cloud top (CTT), just below the inversion, was about $2^{\circ} \mathrm{C}$, so there was no supercooled liquid cloud anywhere in the layer. Immediately above cloud top the air was very dry, but below cloud base water vapor was well-mixed with a specific humidity $\left(q_{\mathrm{v}}\right)$ of about $6 \mathrm{~g} \mathrm{~kg}^{-1}$. The cloud layer itself was about $400 \mathrm{~m}$ deep, and in cloud, $\rho_{\mathrm{L}}$ was near-adiabatic with peak values of around $0.60 \mathrm{~g} \mathrm{~m}^{-3}$ at cloud top. This environment appears to be typical for stratocumulus conditions. Horizontal winds were from the northwest and decreased from 20 to $15 \mathrm{~m} \mathrm{~s}^{-1}$ through the boundary layer, with little directional change at lower levels.

Profile 2 shares a number of features with the classic example of profile 1 , but most notably the $\theta_{\mathrm{v}}$ profile is more complex. The boundary layer top (main $\theta_{\mathrm{v}}$ increase) was at about 1130 ma.s.l. and was coincident with the cloud top, with a temperature of $2{ }^{\circ} \mathrm{C}$. Above this was a cloud-free intermediate layer of about $200 \mathrm{~m}$, in which the specific humidity $\left(q_{\mathrm{v}}\right)$ remained similar to the in-cloud values. There was a weaker $\theta_{\mathrm{v}}$ increase at 1320 ma.s.l., which was coincident with a sharp drop in $q_{\mathrm{v}}$ to nearly zero. At cloud top $\rho_{\mathrm{L}}$ was as high as $0.60 \mathrm{~g} \mathrm{~m}^{-3}$, and was approximately adiabatic in the upper $300 \mathrm{~m}$ of the cloudy layer. Below this, the $10 \mathrm{~s}$ smoothed $\rho_{\mathrm{L}}$ (not shown) reached a minimum of $0.25 \mathrm{~g} \mathrm{~m}^{-3}$ before increasing briefly to $0.35 \mathrm{~g} \mathrm{~m}^{-3}$ and then dropping rapidly as the aircraft continued to descend. We interpret this feature as a cumulus cell rising into the stratocumulus deck above. Winds below cloud displayed a more or less typical Ekman spiral with a directional shift of about $15^{\circ}$ and decrease of $5 \mathrm{~m} \mathrm{~s}^{-1}$ between the cloud base and the lowest flight level.

The intermediate layer between cloud top and the free troposphere had characteristics similar to the "buffer layer" described by Russell et al. (1998), with $q_{\mathrm{v}}$ of similar value to within the boundary layer, but decreasing sharply above the buffer layer. The wind speed was about $5 \mathrm{~m} \mathrm{~s}^{-1}$ lower within this layer than within the boundary layer below or the free troposphere above, but there was no significant directional change. Such intermediate layers were typically identified between the boundary layer and free troposphere in ACE-I. Hande et al. (2012b) identified buffer layers in about $33 \%$ of all Macquarie Island soundings, so while profile 2 may differ from the classic structure of profile 1, it is considered to be common for the SO.

Profiles 3 and 4 are quite different in nature to the more typical profiles discussed above. Both profiles had a boundary layer depth of about $1250 \mathrm{~m}$, with a $0.5^{\circ} \mathrm{C}$ inversion in profile 3 and about $4{ }^{\circ} \mathrm{C}$ in profile 4 .

The cloud that was observed in these profiles occurred in the lower levels where the temperature was exclusively above $0^{\circ} \mathrm{C}$. Conditions were considerably more strongly stably stratified than for profiles 1 and $2\left(\theta_{\mathrm{v}}\right.$ increased with height but was still conditionally unstable), implying that the boundary layer was less well-mixed. The cloud was coincident with high wind shear magnitude, in association with an Ekman spiral below 600 ma.s.l., especially in profile 4. While the cloud fields visually resembled stratocumulus lay- 

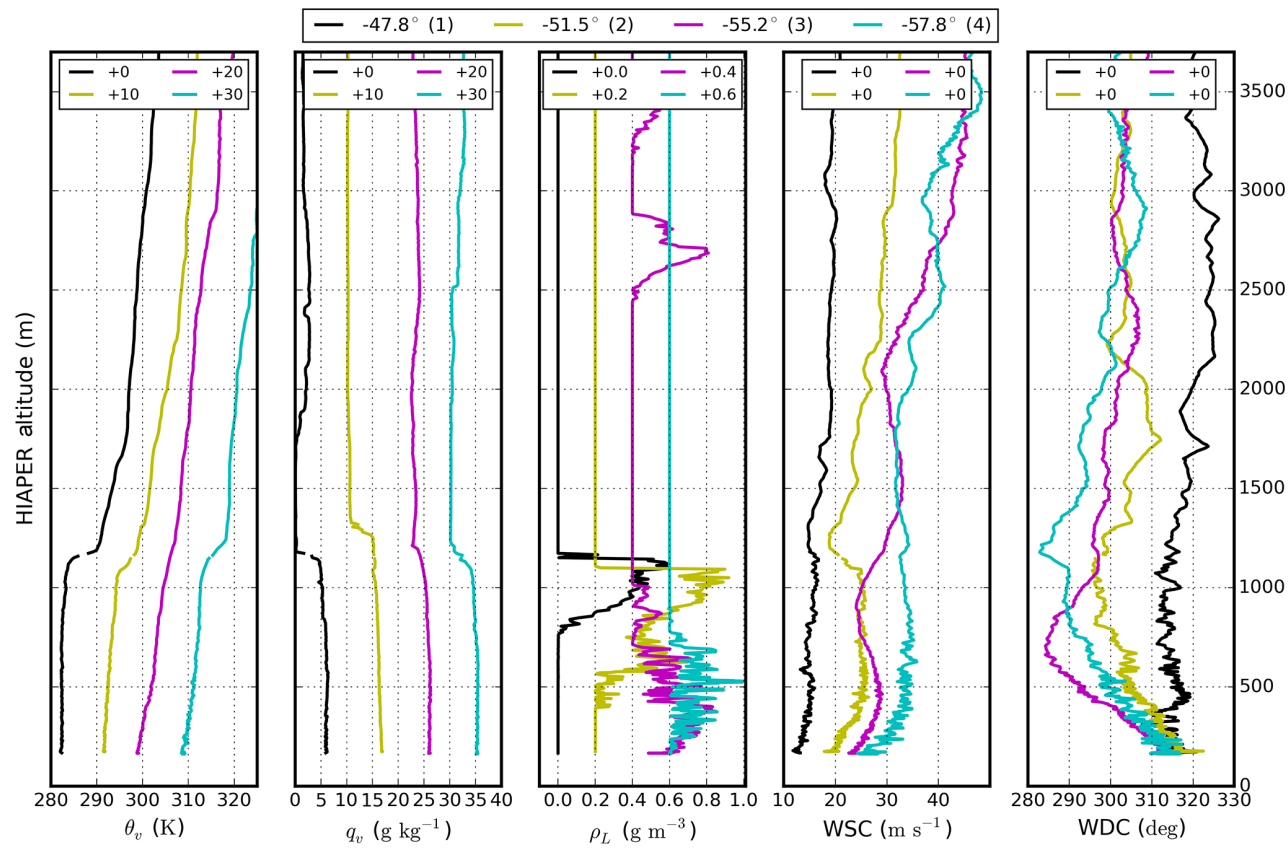

Figure 4. Profiles of thermodynamic variables within and above the boundary layer for RF06. From left: virtual potential temperature $\left(\theta_{\mathrm{V}}\right)$; specific humidity $\left(q_{\mathrm{v}}\right)$; CDP liquid water content $\left(\rho_{\mathrm{L}}\right)$; wind speed (WSC); and wind direction (WDC). The colors indicate the profile number and location (see top panel). Note that for display purposes, the values for some profiles have been offset by the amount indicated in the legend in each panel.

ers (see Fig. 3), peak $\rho_{\mathrm{L}}$ values were not located near cloud top as they were in profiles 1 and 2 . The cloud field in profile 3 was fairly continuous and flat-topped, but some gaps could be identified during the descent. Cloud top was less well defined in profile 4, with larger broken regions, and highly variable $\rho_{\mathrm{L}}$ values suggesting that clear air was sampled between cloud patches. Patchy mid-level cloud layers were also sampled between 2500 and $4500 \mathrm{~m}$ a.s.l. for both of these profiles, but some of these were beyond the altitude range plotted in Fig. 4.

The boundary layer wind speeds for profiles 3 and 4 were very high. Winds of $29 \mathrm{~m} \mathrm{~s}^{-1}$ in profile 3 were observed at around $500 \mathrm{ma}$ a.s.l. Above this altitude, winds receded slightly to about $25 \mathrm{~m} \mathrm{~s}^{-1}$ at $1000 \mathrm{~m}$ a.s.l. (the boundary layer top), then increased with height to a maximum of about $33 \mathrm{~m} \mathrm{~s}^{-1}$ in the lower free troposphere. The winds at the lowest level of flight were at least $23 \mathrm{~m} \mathrm{~s}^{-1}$, which is likely in the range for spume production at the ocean surface. Profile 4 was windier still, with peak wind speeds in the boundary layer of nearly $35 \mathrm{~m} \mathrm{~s}^{-1}$, and the wind speed was consistently greater than $30 \mathrm{~m} \mathrm{~s}^{-1}$ for altitudes above about $250 \mathrm{~m}$ a.s.l. At the lowest level of flight, the wind speed was greater than $25 \mathrm{~m} \mathrm{~s}^{-1}$. Using a log scaling law to translate this to surface conditions, the $10 \mathrm{~m}$ winds would have been gale force $\left(\geq 17 \mathrm{~m} \mathrm{~s}^{-1}\right)$.

\subsection{Microphysics variables}

Profiles of CDP cloud droplet number concentration and mean diameter, as well as UHSAS aerosol number concentration and 2DC-derived rain rate, calculated from the 2DC observations using droplet fall speeds from Pruppacher et al. (1998), are provided in Fig. 5. Where $\rho_{\mathrm{L}}$ did not meet the criteria discussed in Sect. 2, data from the CDP and UHSAS are shown with dashed lines. More information about particle size within cloud and below cloud base is given by the particle size distributions (PSDs) in Fig. 6, which we discuss in detail in this section.

The cloud droplet number concentration $N_{\mathrm{C}}$ in profile 1 was relatively uniform throughout the cloud with a mean value of $45 \mathrm{~cm}^{-3}$, which is perfectly consistent with the established literature (e.g. Boers and Krummel, 1998; Boers et al., 1998; Yum and Hudson, 2004, etc.) on wintertime cloud microphysical conditions over the pristine SO. Cloud droplet mean diameter $\overline{D_{\mathrm{C}}}$ increased from about $10 \mu \mathrm{m}$ near cloud base to about $27 \mu \mathrm{m}$ near cloud top. The cloud droplet effective radius $\left(r_{\mathrm{e}}\right.$; Hansen and Travis, 1974), calculated from the PSD was $14.4 \mu \mathrm{m}$. This is just above the threshold suggested by Rosenfeld and Gutman (1994) for precipitation, and indeed instantaneous rain rates near cloud base of up to $0.2 \mathrm{~mm} \mathrm{~h}^{-1}$ were calculated, with drizzle drops of diameter up to $400 \mu \mathrm{m}$ observed.

The picture was similar for profile 2 , where peak $\rho_{\mathrm{L}}$ values were comparable, but the mean droplet number concentra- 

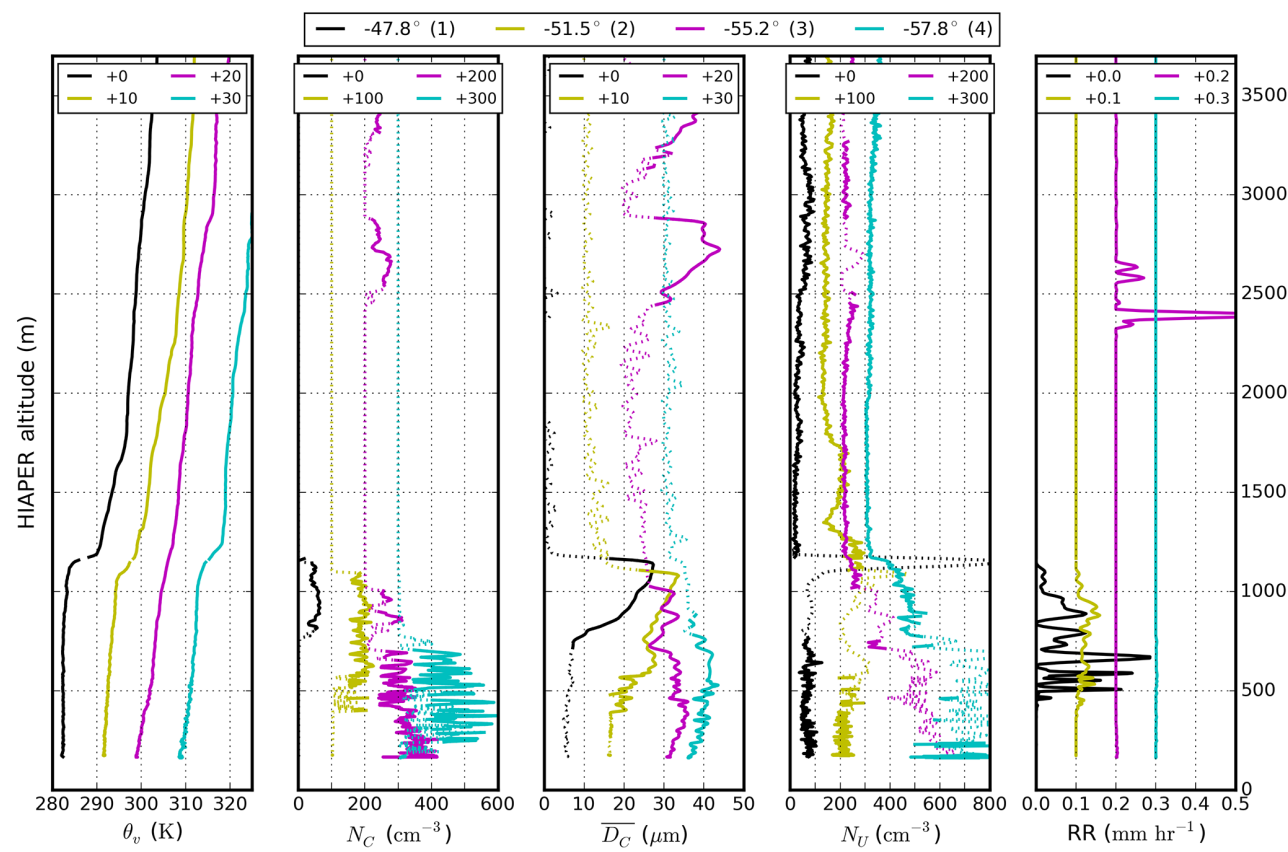

Figure 5. Profiles of microphysics variables within and above the boundary layer for RF06, with offsets for each profile indicated in the legend. From left: virtual potential temperature $\left(\theta_{\mathrm{v}}\right.$, repeated for reference to other variables); CDP number concentration $\left(N_{\mathrm{C}}\right.$, dashed where $\left.\rho_{\mathrm{L}}<0.05 \mathrm{~g} \mathrm{~m}^{-3}\right)$; CDP mean diameter $\left(\overline{D_{\mathrm{C}}}\right.$, dashed where $\left.\rho_{\mathrm{L}}<0.05 \mathrm{~g} \mathrm{~m}^{-3}\right)$; UHSAS number concentration $\left(N_{\mathrm{U}}\right.$; dashed where $\rho_{\mathrm{L}}>0.01 \mathrm{~g} \mathrm{~m}^{-3}$ ); and 2DC-derived rain rate (RR).

tion was higher $\left(N_{\mathrm{C}}=77 \mathrm{~cm}^{-3}\right)$ and the diameters smaller $\left(\overline{D_{\mathrm{C}}}=23 \mu \mathrm{m}\right.$ and $r_{\mathrm{e}}=13 \mu \mathrm{m}$ near cloud top). The 2DCderived rain rate for this cloud was much lower, with maximum values around $0.05 \mathrm{~mm} \mathrm{~h}^{-1}$.

In profile 3, the HIAPER encountered some broken cloud at 900-1000ma.s.l., and contiguous cloud between 167 ma.s.l. (the minimum altitude reached) and $700 \mathrm{ma.s.1}$. In the deeper cloud $\rho_{\mathrm{L}}$ was quite variable, but $N_{\mathrm{C}}$ was uniformly about $100 \mathrm{~cm}^{-3}$ in the top $300 \mathrm{~m}$, and increased to about $150 \mathrm{~cm}^{-3}$ between 167 and $400 \mathrm{~m}$ a.s.l., with peak values above $200 \mathrm{~cm}^{-3} \cdot \overline{D_{\mathrm{C}}}$ tended to vary with $\rho_{\mathrm{L}}$, and had an average value of $14 \mu \mathrm{m}$, and $r_{\mathrm{e}}$ near cloud top was about $8.6 \mu \mathrm{m}$. Virtually no drops larger than $100 \mu \mathrm{m}$ were imaged by the $2 \mathrm{DC}$.

In profile 4 the HIAPER appears to have flown through patchy or broken cloud, with $\rho_{\mathrm{L}}$ falling below both the 0.05 and the $0.01 \mathrm{gm}^{-3}$ thresholds at several points during the profile. Within the patchy cloud it is difficult to establish a representative $N_{\mathrm{C}}$ value, because over any given averaging interval there may have been a mixture of clear air and cloud. In a 10-s interval near cloud top, the mean value was $144 \mathrm{~cm}^{-3}$, but at the altitude of maximum $\rho_{\mathrm{L}}$ the mean value was $203 \mathrm{~cm}^{-3}$. The $1 \mathrm{~Hz}$ peak values, which are possibly the best estimate of the "adiabatic" cloud droplet concentration (Yum and Hudson, 2004), were up to $300 \mathrm{~cm}^{-3} \cdot \overline{D_{\mathrm{C}}}$ varied very little from $10-12 \mu \mathrm{m}$, and $r_{\mathrm{e}}$ near cloud top was $7.0 \mu \mathrm{m}$. Very few drizzle drops greater than $100 \mu \mathrm{m}$ diameter were observed in this profile.
UHSAS aerosol concentration $\left(N_{\mathrm{U}}\right.$; fourth panel of Fig. 5) observations are not a direct measurement of cloud condensation nuclei $(\mathrm{CCN})$ concentrations, but they are all that was available for sub-micron airborne particles during HIPPO4. One of the first things that we noted was the particularly low concentration of particles immediately above the boundary layer in each of the four profiles. Values of $N_{\mathrm{U}} \sim 10$ $20 \mathrm{~cm}^{-3}$ were typical (except for profile 2, see Sect. 4.1). To put these values in context, at similar latitudes in HIPPO-4 RF10, a flight from Midway to Anchorage, Alaska on 7 July 2011 , tropospheric $N_{\mathrm{U}}$ values (not shown) were typically above $100 \mathrm{~cm}^{-3}$ and values above $500 \mathrm{~cm}^{-3}$ were observed in two profiles.

In profile 1, there was a large spike in $N_{\mathrm{U}}$ at cloud top, with values reaching well above $600 \mathrm{~cm}^{-3}$, which is likely an artifact of splashing droplets. We discuss this further in Sect. 5.2. In clear air below the cloud, $60 \mathrm{~s}$ averages $N_{\mathrm{U}}$ of $82 \mathrm{~cm}^{-3}$ (which corresponded to 1.8 times the in-cloud $N_{\mathrm{C}}$ ) were observed. There was a narrow, well-established accumulation mode (usually associated with cloud processing) centered on $0.13 \mu \mathrm{m}$, and the broad SSA mode was centered on $0.18 \mu \mathrm{m}$. Profile 2 shows a similar but smaller spike in $N_{\mathrm{U}}$ at cloud top which we again attribute to droplet breakup. Below-cloud values were on average $110 \mathrm{~cm}^{-3}$, or about 1.4 times $N_{\mathrm{C}}$. The accumulation mode was centered on $0.15 \mu \mathrm{m}$, and the SSA mode was centered on $0.2 \mu \mathrm{m}$. Just above the cloud, at about 1500 ma.s.l., $N_{\mathrm{U}}$ reached $100 \mathrm{~cm}^{-3}$ in a layer about $300 \mathrm{~m}$ deep; an interesting feature which we discuss in Sect. 4.2. 

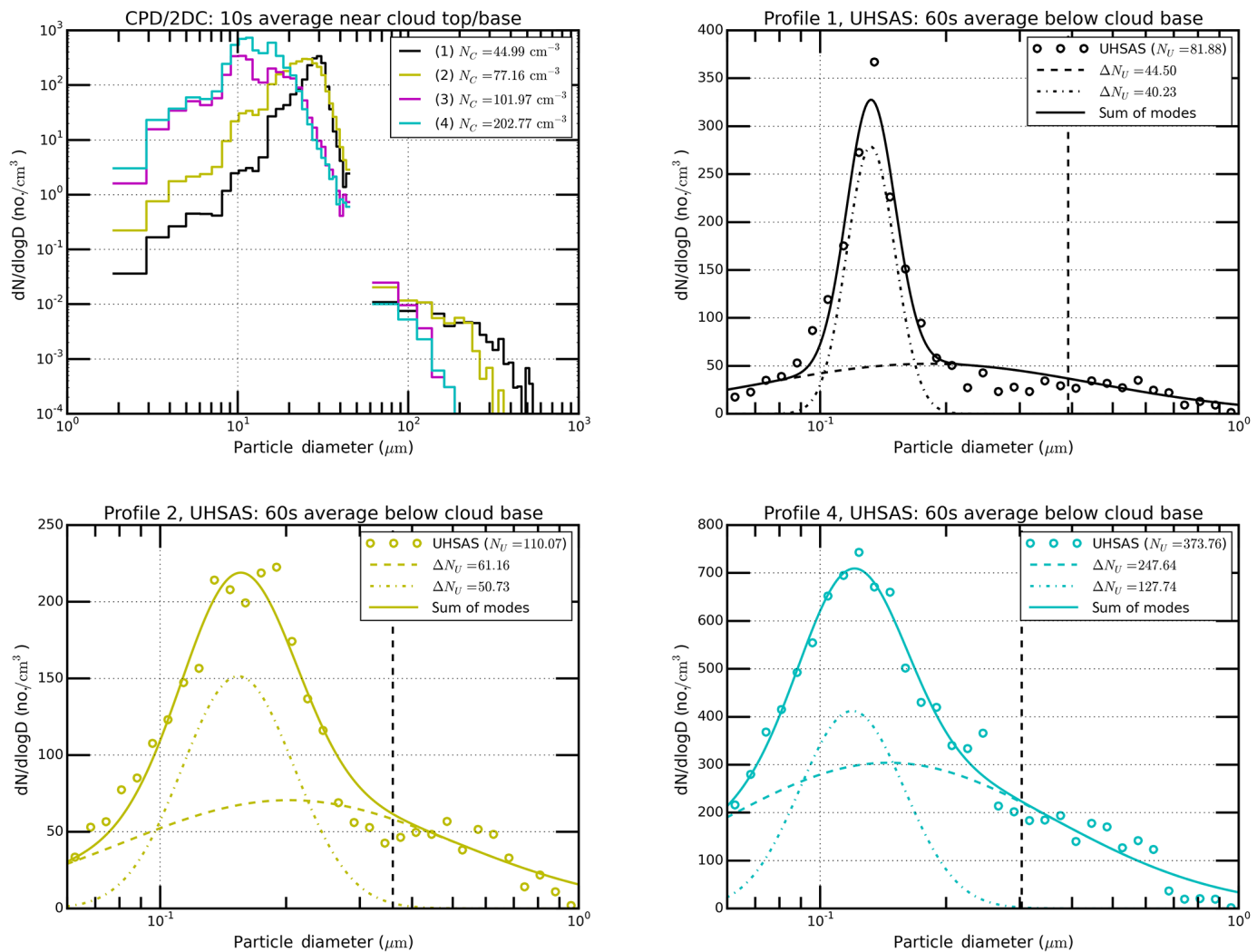

Figure 6. Particle size distributions (PSDs) during HIPPO-4. Upper left panel: 10 s average cloud droplet PSDs observed by the CDP near cloud top, and drizzle drop PSDs observed by the 2DC near cloud base. Note the logarithmic $y$ scale for this panel. Upper right, and lower panels: $60 \mathrm{~s}$ average PSDs for UHSAS data for profiles 1, 2 and 4 as labeled, with fitted modes shown by dashed lines. The contribution to the observed $N_{\mathrm{U}}$ for each mode is shown in the legend, and the cutoff size used for identifying the SSA mode marked by a black dashed line (see text). Note the different scales on the $y$ axes.

The HIAPER did not descend below cloud base during profile 3, so a size distribution is not shown. However, relatively clear air between clouds at 700 and $850 \mathrm{~m}$ a.s.l. was sampled. In this gap $N_{\mathrm{U}}$ was about $150 \mathrm{~cm}^{-3}$, but this might not be representative of below-cloud values. The below cloud $60 \mathrm{~s}$ average value of $N_{\mathrm{U}}$ in the lowest leg of profile 4 was $374 \mathrm{~cm}^{-3}$ (1.8 times the in-cloud $\left.N_{\mathrm{C}}\right)$. The accumulation mode was centered on $0.12 \mu \mathrm{m}$, which is somewhat smaller than for profiles 1 and 2. The SSA mode was centered on $0.15 \mu \mathrm{m}$, which was similar to the accumulation mode for this profile.

For profiles 1 and 2, the modal decomposition suggested that the SSA mode contributed about $55 \%$ of the total $N_{\mathrm{U}}$. The contribution of the SSA mode was much greater for profile 4, where it accounted for $70 \%$. In an absolute sense, the SSA mode was more than four times larger in profile 4 than in profiles 1 and 2. This suggests that SSA had a much stronger contribution to the total $N_{\mathrm{U}}$ for this profile than the those taken to the north.

\subsection{Summary of flight data observations}

During a single flight the HIAPER sampled boundary layer cloud, all at temperatures above $0^{\circ} \mathrm{C}$, in a range of different meteorological conditions. In the northernmost profiles (1 and 2), the boundary layer structure was "typical" for the SO: fairly well-mixed (in particular for profile 1) and neutrally stable, and capped with stratocumulus cloud. The microphysical conditions were within the envelope of expected values for the SO. To the south, conditions were much more thermodynamically stable (although still conditionally unstable) and poorly-mixed, and were characterized by high shear in gale-force winds. The values of $N_{\mathrm{C}}$ and $N_{\mathrm{U}}$ here were well outside the envelope that we would expect for pristine maritime conditions over the SO based on previous in situ studies. Modal decomposition analysis of the UHSAS PSD suggests that SSA dominated the aerosol population for profile 4. 

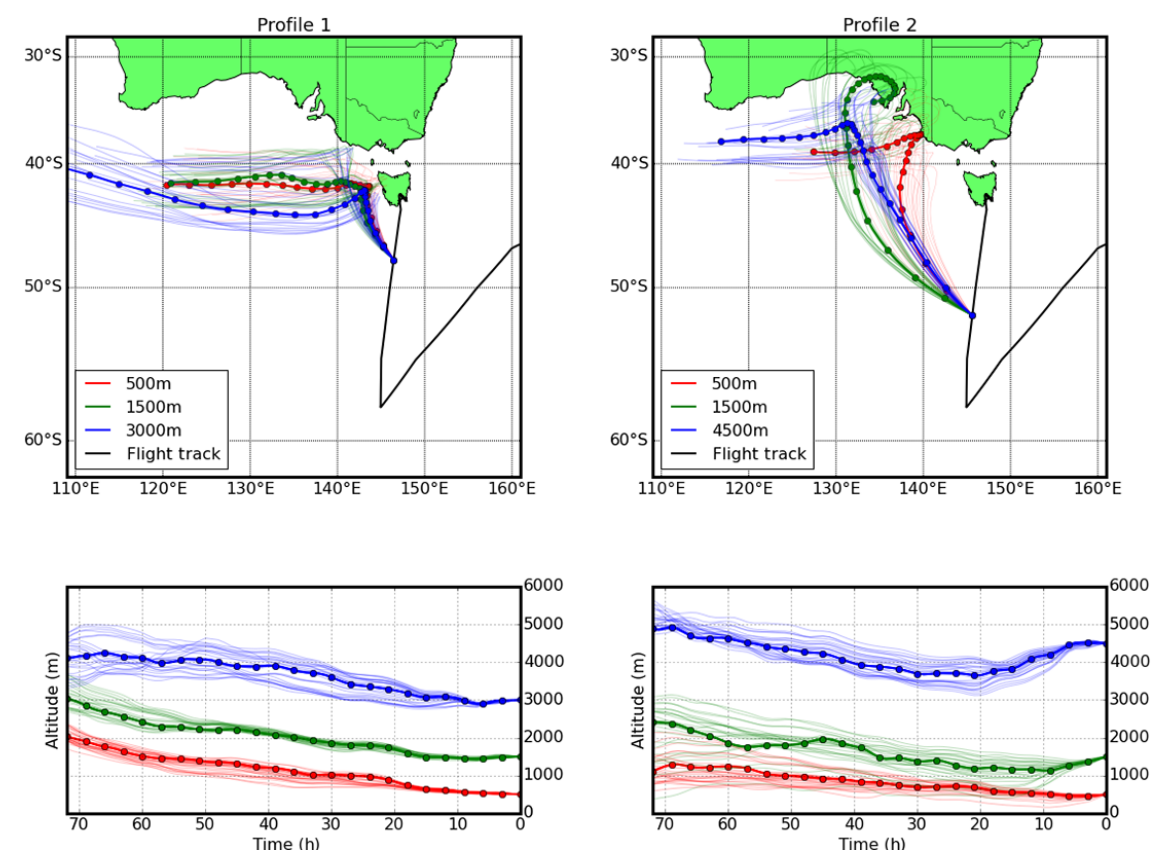

Figure 7. $72 \mathrm{~h}$ HYSPLIT Back trajectory ensembles for profiles 1 and 2, with arrival heights indicated in the legends. Back trajectories were calculated with $1^{\circ}$ horizontal resolution Global Data Assimilation System meteorological data, with the different ensemble members representing perturbations from the aircraft location of 1 grid space in the horizontal and $0.01 \sigma$ (about $250 \mathrm{~m}$ ) in the vertical. The "deterministic" trajectories are heavier weighted lines with 3 hourly circle markers for each ensemble.

\section{Airmass identification}

In this section we present an analysis of back trajectories calculated as per Sect. 2.5, at points along the flight path of the HIAPER during HIPPO-4 RF06, to provide further context for our assessment of the microphysical and atmospheric chemistry observations below.

\subsection{Back trajectories}

Figure 7 shows ensembles of back trajectories for profiles 1 and 2. For profile 1, the most "classic" of the profiles, the westerly motion 2 to 3 days before arriving along the flight track occurred while the subtropical ridge was confined to the continent some $48 \mathrm{~h}$ earlier (not shown), resulting in strong westerly winds along $40^{\circ} \mathrm{S}$. As the blocking anticyclone moved and intensified over Tasmania, the trajectories stagnated and turned southwards with the approach of the cold front. The vertical motion was weakly descending and there was very little spread between the trajectories, as expected in the weak subsidence beneath the anticyclone. None of the ensemble members appear to pass over the mainland, but some cross over the coastline of remote western Tasmania.

In profile 2, it is evident from the spacing of the 3 hourly markers in the "deterministic" trajectories that the winds were much stronger than for profile 1 . Although far displaced from the cold front itself, these trajectories were more clearly driven by the pre-frontal motion, which is shown especially by the gradual ascent (about $1.5 \mathrm{~cm} \mathrm{~s}^{-1}$ ) in the $3000 \mathrm{~m} \mathrm{en-}$ semble during the $20 \mathrm{~h}$ prior to arrival, and in the $1500 \mathrm{~m}$ ensemble during the $10 \mathrm{~h}$ prior to arrival. All of the ensembles include trajectories which appear to have spent time over the coastal mainland immediately before strong advection from the north. The 1500 ma.s.l. "deterministic" trajectory and a large number of the ensemble members passed in the general vicinity of Port Pirie, a heavy industry center in South Australia, some 24 to $36 \mathrm{~h}$ before arriving at the location of profile 2 . The same was true for an ensemble arriving at $3000 \mathrm{~m}$, but this is not shown. None of the members for the $4500 \mathrm{~m}$ ensemble passed over land.

The trajectories for profile 3 (Fig. 8) are considerably more complex. Our estimate for the distance ahead of the cold front, accounting for frontal motion between the ERAInterim analysis at 00:00 UTC (Fig. 1) and the time on location, is about $200 \mathrm{~km}$. It appears that some of the trajectory ensemble members were initialized to the west of (i.e. behind) the cold front, and others to the east, because there was considerable divergence in the airmass history. For each arrival height, some of the ensemble members originated from around the Nullarbor Plain, an unpopulated and sparsely vegetated coastal region in Western and South Australia; and some members originated over the remote Indian/Southern Ocean and did not pass over any land. The bifurcation is apparent in the trajectory altitude as well: those that originated near the continent (around $130^{\circ} \mathrm{E}, 30^{\circ} \mathrm{S}$ ) ahead of the front 

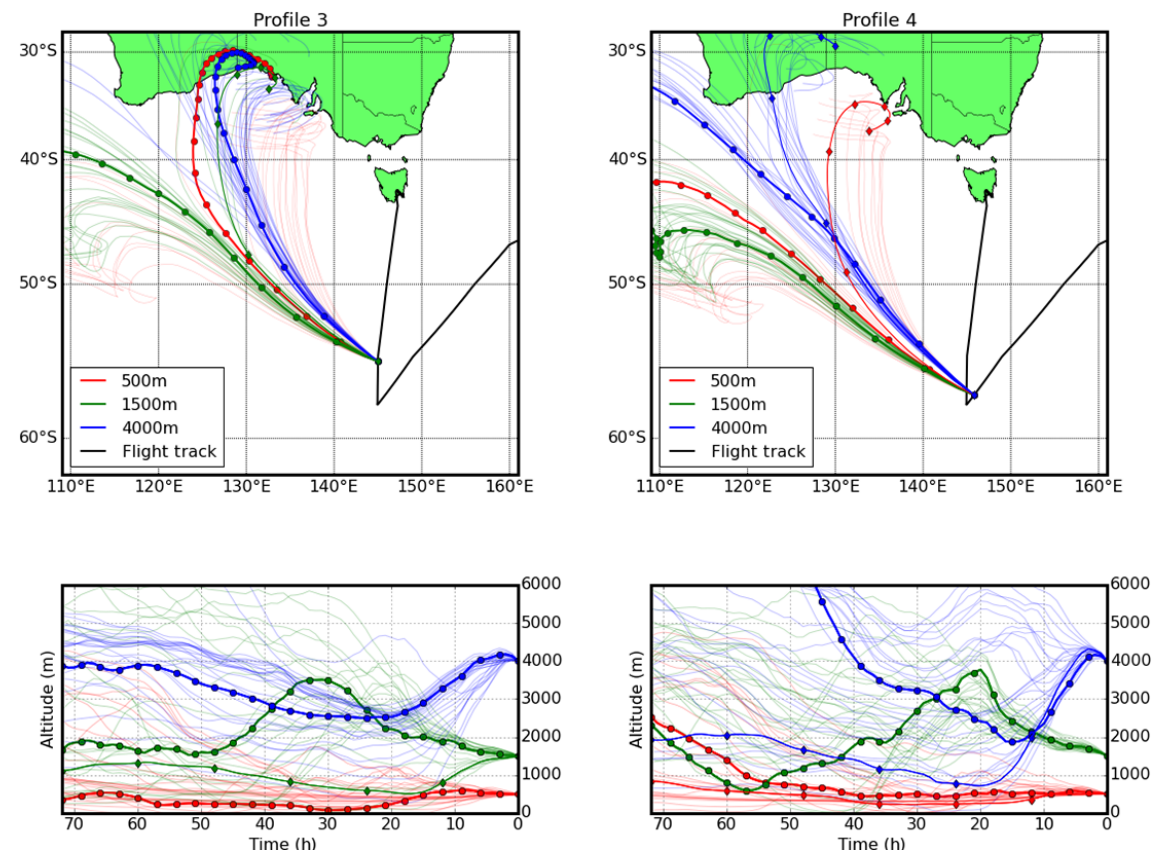

Figure 8. As for Fig. 7, but for profiles 3 and 4. In this figure some additional ensemble members, which represent substantially different airmass histories from the "deterministic" trajectories, have been highlighted with 12 hourly diamond markers.

generally had ascending trajectories in the $20 \mathrm{~h}$ prior to arrival at profile 3 , and those that originated over the remote oceans had descending trajectories.

Profile 4 was performed even closer to the cold front, so there is again substantial divergence in the airmass history. Based on the location provided in the ERA-Interim analysis, the aircraft was about $160 \mathrm{~km}$ ahead of the cold front, but the "deterministic" trajectories appear to have been initialized behind the front in the GDAS analysis. Although none of the ensemble members arriving at either 500 or $1500 \mathrm{~m}$ a.s.l. passed directly over land, a group arriving at $500 \mathrm{ma}$ a.s.l. originated from near the South Australian coastline some $48 \mathrm{~h}$ earlier. On the other hand, the group of trajectories with pre-frontal characteristics arriving at $4000 \mathrm{~m}$ a.s.l. were over south Western Australia at low altitudes about $24 \mathrm{~h}$ earlier.

In summary, the profile with the strongest case for continental and/or anthropogenic influence is profile 2 , which had ensemble members at all levels passing nearby known areas of industrial activity. The likelihood of interaction with continental and/or anthropogenic aerosol sources decreased for profiles further to the south, where there was some evidence for continental contribution at around 4000 ma.s.l., but not within the boundary layer.

\subsection{Analysis of chemistry data with respect to back trajectories}

Figure 9 shows $\mathrm{CO}, \mathrm{BC}$, and $N_{\mathrm{U}}$ for the entire vertical extent of the four profiles. In profile 1, there was a weak increase in $\mathrm{CO}$ (up to $60 \mathrm{ppbv}$ ) and $N_{\mathrm{U}}$ (up to $75 \mathrm{~cm}^{-3}$ ) between 2000 and $4000 \mathrm{~m}$, but no signal in $\mathrm{BC}$ and minimal interaction with the continental airmass. $\mathrm{CO}$ also increased with height above $5500 \mathrm{~m}$, but there was no signal in either BC or $N_{\mathrm{U}}$ at these levels.

The strongest chemical signal in profile 2 , and indeed all of the profiles, is in a layer between 4000 and $5000 \mathrm{~m}$ a.s.1., where elevated, highly correlated $\mathrm{CO}$ and $\mathrm{BC}$ concentrations were observed. This is characteristic of combustion, but we found that trajectories arriving at $4500 \mathrm{~m}$ a.s.l. did not have the clear terrestrial interaction that 1500 and $3000 \mathrm{~m}$ (not shown) a.s.l. trajectories had, and aerosol concentrations were quite low $\left(N_{\mathrm{U}} \simeq 30 \mathrm{~cm}^{-3}\right)$ at these levels. Just above cloud top at $1500 \mathrm{~m}$ a.s.l., $N_{\mathrm{U}}$ was slightly elevated at $100 \mathrm{~cm}^{-3}$, which corresponded to a small increase in both $\mathrm{CO}$ and $\mathrm{BC}$, and the back trajectories at this level had a clear terrestrial interaction. In any case, if these observations are indeed evidence of long-range transport of anthropogenic pollution, the impact on the aerosol loading was small.

If there was terrestrial interaction for the air sample in profile 3, the signals in the observations were weak. Due to the presence of cloud and precipitation, $\mathrm{BC}$ observations were unavailable at 3000-4000 ma.s.1., but slightly elevated CO concentrations at about $4000 \mathrm{~m}$ a.s.l. correspond to increased $N_{\mathrm{U}}$ of about $50 \mathrm{~cm}^{-3}$ from values of $10-20 \mathrm{~cm}^{-3}$ just above the boundary layer.

At $4000 \mathrm{~m}$ a.s.l. in profile 4 , there was a slight increase in the tropospheric $\mathrm{CO}$ concentration, with values up to $60 \mathrm{ppbv}$, or $10 \mathrm{ppbv}$ higher than the values at the top of the boundary layer. This corresponded to a small peak in the $N_{\mathrm{U}}$ concentration of about $80 \mathrm{~cm}^{-3}$, but $\mathrm{BC}$ observations, which 


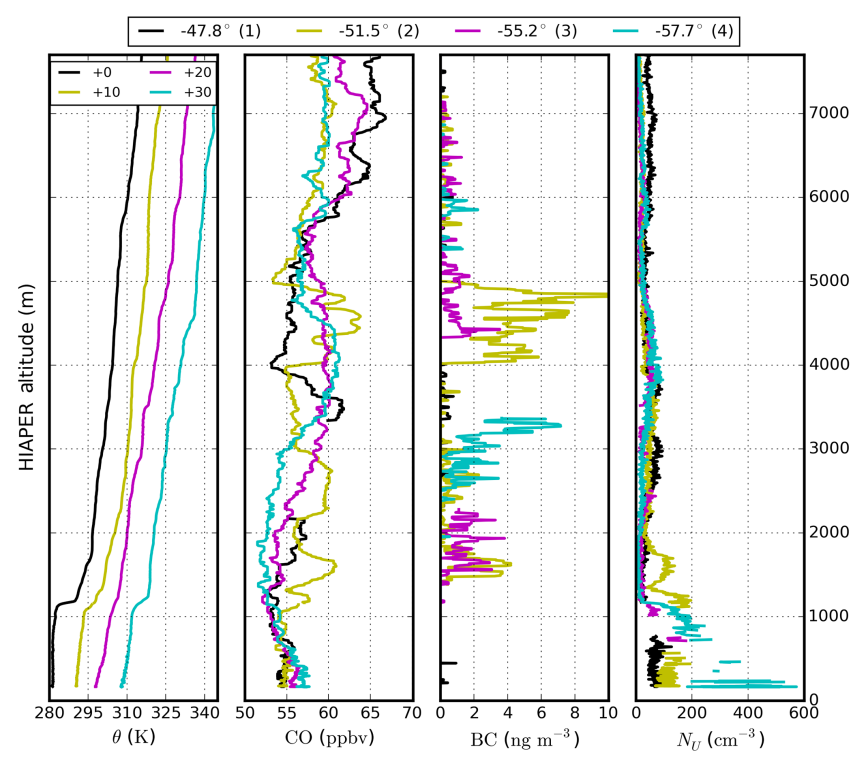

Figure 9. Trace gas and aerosol profiles for comparison flight RF06. From left: potential temperature $(\theta$, note offset of $10 \mathrm{~K}$ between profiles); Aerolaser VUV resonance fluorescence carbon monoxide concentration (CO); SP2 black carbon (BC) mass concentration; and UHSAS number concentration $\left(N_{\mathrm{U}}\right.$; missing for in-cloud conditions). Note that the $y$ scale is different to Figs. 4 and 5, and now shows the entire vertical extent of the profiles.

were trending upwards with altitude below this, were missing here as well. Given that some of the trajectory ensemble members originated over land at low altitude, this could be evidence of diluted continental or anthropogenic influence. This feature is clearly decoupled from the boundary layer, as evidenced by $N_{\mathrm{U}}$ values strictly below $20 \mathrm{~cm}^{-3}$ and $\mathrm{CO}$ concentration of $52 \mathrm{ppbv}$ between 1250 and $2000 \mathrm{~m}$ a.s.l. Within the boundary layer itself, $\mathrm{CO}$ concentrations increase towards the surface to a maximum of $57 \mathrm{ppbv}$ at $167 \mathrm{ma.s.1}$. Without BC observations at these levels, it is difficult to attribute the source of this $\mathrm{CO}$ to human activity (combustion) or natural marine sources. In either case, $N_{\mathrm{U}}$ varied much more in the boundary layer than it did near 4000 ma.s.l. for a similar variation in $\mathrm{CO}$, so it is difficult to attribute the elevated $N_{\mathrm{U}}$ to long-range transport.

\subsection{Comparison to clearly polluted and/or pristine cases}

It is useful to provide some context to our discussion of a possible anthropogenic pollution plume by considering some other flights. In HIPPO-4 RF07 (the subsequent flight, 2 days later), the HIAPER flew from Hobart to Darwin and performed a descending and an ascending profile over the Bass Straight, almost directly south of Melbourne. Conditions (not shown) were somewhat different to profile 1 of RF06, with a deeper boundary layer (capping inversion at $1900 \mathrm{~m}$ a.s.1.); lower wind speed (about $10 \mathrm{~m} \mathrm{~s}^{-1}$ ); and there was no cloud.
The wind direction between 600 and 1500 ma.s.l. was directly from the north, and in this layer the pollution plume from the Melbourne urban area can be unequivocally identified in Fig. 10, which shows observations for the entire vertical extent of the profiles of $\theta, \mathrm{CO}, \mathrm{BC}$, and $N_{\mathrm{U}}$. Concentrations of $\mathrm{CO}$ were about 20-30 ppmv higher within the plume than in the free troposphere. $N_{\mathrm{U}}$ of up to $2000 \mathrm{~cm}^{-3}$ was observed, and the values were very highly correlated with both $\mathrm{BC}$ and $\mathrm{CO}$ concentrations $(R=0.87$ and $R=0.95$ respectively). On the other hand, the free troposphere was extremely clean based on the $\mathrm{CO}$ values of about $55 \mathrm{ppbv}, \mathrm{BC}$ of virtually zero, and $N_{\mathrm{U}}$ of $20-40 \mathrm{~cm}^{-3}$.

In HIPPO-3 RF06 (not shown), a return flight from Christchurch to $67^{\circ} \mathrm{S}$ in the previous campaign (April 2010) and the subject of Chubb et al. (2013), undoubtedly pristine maritime conditions were encountered. Low-level CO concentrations were about $41 \mathrm{ppbv}$ (this may be a seasonal difference compared to HIPPO-4 RF06), but still varied by about 5 ppbv between 5000 and $7000 \mathrm{~m}$ a.s.l. BC concentrations were practically zero in all profiles, and $N_{\mathrm{U}}$ concentrations were less than $20 \mathrm{~cm}^{-3}$ in the free troposphere but rose to around $100 \mathrm{~cm}^{-3}$ in the lowest levels sampled.

With these two comparison flights in mind, HIPPO-4 RF06 (the present flight) is neither an example of a pristine SO environment nor a heavily modified one. As discussed above, there is mixed evidence for anthropogenic influence in each of the profiles. However, the weak signals that can be identified occur well above the boundary layer, where back trajectories can in some cases be used to link the history of the air to anthropogenic sources. The air within the boundary layer, on the other hand, does not display an anthropogenic signature that could explain the elevated $N_{\mathrm{U}}$ values.

\subsection{What about mineral dust?}

So far our analysis has concentrated on sources of aerosol associated with combustion, and therefore associated with $\mathrm{CO}$ and BC. However, there is the possibility that naturally occurring continental dust could have been the cause of the elevated $N_{\mathrm{U}}$ and $N_{\mathrm{C}}$ values in profiles 3 and 4 . Indeed, dust from the Australian continent has been hypothesized to be an important fertilizing agent for SO phytoplankton (Martin, 1990), and dust samples from Antarctica have been geochemically linked to Australian sources (Revel-Rolland et al., 2006).

While the principal sources of Australian dust are further to the east in the Murray-Darling Basin (De Deckker et al., 2010), the Nullarbor Plain is a known secondary source of dust. However, the month of June 2011 was relatively wet in the Nullarbor Plain, temperatures were about average for winter, and wind speeds in the days before HIPPO-4 RF06 were unremarkable. Furthermore, observations of suspended dust are routinely reported at Australian Bureau of Meteorology from a number of sites in the Nullarbor (O'Loingsigh et al., 2014), and there were no reports of any suspended dust 


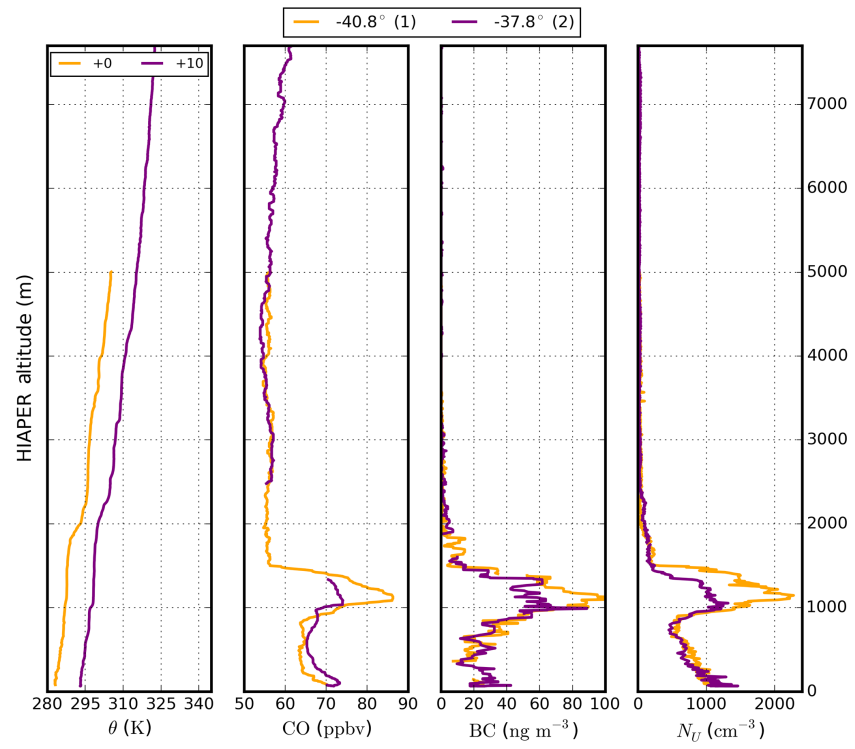

Figure 10. As for Fig. 9, but for RF07, showing a clear example of a polluted plume over the Bass Straight to the south of Melbourne. Note different $x$ scales for $\mathrm{CO}, \mathrm{BC}$, and $N_{\mathrm{U}}$ compared to Fig. 9.

in the week before the flight (T. O'Loingsigh, personal communication, 2015).

Another argument comes directly from the trajectories (and as such applies also to the hypothesis of anthropogenic aerosols): the trajectories with continental interaction arriving at 500 and $1500 \mathrm{~m}$ a.s.l. in profile 3 are very similar, both in the horizontal and vertical. If the elevated $N_{\mathrm{U}}$ values in the boundary layer were due to dust, we should expect to find similar $N_{\mathrm{U}}$ values at $1500 \mathrm{~m}$ as well, but they were an order of magnitude lower. The same argument applies to profile 4 , where trajectories arriving at $4000 \mathrm{~m}$ a.s.l. may have been near the surface of south Western Australia about $36 \mathrm{~h}$ before, but $N_{\mathrm{U}}$ values at these levels were small in comparison to the boundary layer values.

\subsection{Can we explain elevated droplet and aerosol concentrations by considering potential anthropogenic or continental sources?}

To summarize the results of this section, we used the combination of back trajectory ensembles with in situ observations as a tool to identify continental/anthropogenic aerosol influences. In profiles 3 and 4 there was evidence of weak anthropogenic influence between 3000 and $5000 \mathrm{~m}$ a.s.l. through the increase of $N_{\mathrm{U}}$ in association with BC and CO. When compared to profiles through a clear pollution plume in another flight, it is evident that any influence in HIPPO-4 RF06 was highly diluted. Furthermore, given similar $\mathrm{CO}$ signals in the boundary layer as in the upper levels, the $N_{\mathrm{U}}$ values were far too high to be attributed to anthropogenic pollution. In addition, we were unable to identify any dust storm activ- ity around the Nullarbor in the week before the flight, and surface observations suggest that dust activity was unlikely. The trajectory analysis suggested that dust, if present, should have resulted in similarly increased $N_{\mathrm{U}}$ values in both the troposphere and the boundary layer, but there was an order of magnitude difference between the two.

The conclusion that we draw from this analysis is that the elevated $N_{\mathrm{C}}$ and $N_{\mathrm{U}}$ values within the boundary layer can not be predominantly attributed to long-range transport of anthropogenic pollution or continental dust.

\section{Evaluation of observational uncertainties}

\subsection{CDP observations}

The accuracy of the CDP is typically stated as $\pm 10 \%$ due to uncertainties in the true sample volume and in the sizing of small particles through Mie scattering. However, the PMS-King probe consistently showed about 0.68 of $\rho_{\mathrm{L}}$ from the CDP. Using a parcel ascent model (which conserved $\theta_{\mathrm{e}}$ ) initialized with conditions near cloud base for profile 1 , we calculated the theoretical adiabatic $\rho_{\mathrm{L}}$ for this cloud. This calculation suggested that the value at cloud top would be about $0.64 \mathrm{gm}^{-3}$, very close to the CDP value of $0.60 \mathrm{gm}^{-3}$. When all observations within this cloud were compared to the theoretical adiabatic values through linear regression, excluding a small region where entrained air was apparent, the observations were found to agree to within $1 \%$. This analysis, combined with the beam mapping performed by the manufacturer, suggests very strongly that the CDP observations were robust.

Even if the CDP did significantly overestimate $\rho_{L}$ - which we believe to be unlikely - it may have also overestimated $N_{\mathrm{C}}$ by the same fraction, depending on the cause of the error. However, this would ultimately have little impact on our conclusions, because it would still be necessary to explain a factor of five increase in $N_{\mathrm{C}}$ between profiles 1 and 4 .

\subsection{UHSAS observations in ambiguous conditions}

Vidaurre and Hallett (2009) established droplet breakup criteria upon impact with a cylindrical surface based on the Weber number, or the ratio of particle impact kinetic energy to surface energy. This depended primarily on particle diameter and speed of impact (which is in turn dependent on the inlet geometry). For a representative airspeed of the HIAPER and geometry of the UHSAS inlet, their criteria predict that droplet breakup should be minimal for droplets with diameters under about $8 \mu \mathrm{m}$, but severe for droplets with diameters over about $20 \mu \mathrm{m}$.

In profiles 1 and 2, the air beneath the cloud was unequivocally clear, with zero $N_{\mathrm{C}}$ observed by the CDP, so we have no concerns about droplet splashing affecting these data.

In profile 3 , the cloud-free $\rho_{\mathrm{L}}<0.01 \mathrm{gm}^{-3}$ threshold was never met in the lowest leg and droplet diameters of 10 
$12 \mu \mathrm{m}$ were observed. These droplet sizes could have caused splashing on the UHSAS inlet so we do not consider these data. However there was some suitably clear air for a short interval between clouds during descent, and we consider these data to be usable, although perhaps not representative of below-cloud values.

The case for the robustness of the UHSAS data in profile 4 is much better. The air sampled during the lowest leg met our "probably clear" criterion of $\rho_{\mathrm{L}}<0.05 \mathrm{gm}^{-3}$. However, there was a non-zero cloud droplet concentration in most 1$\mathrm{s}$ intervals, and $N_{\mathrm{C}}$ was in the range of $6-10 \mathrm{~cm}^{-3}$ ( $\rho_{\mathrm{L}}$ was $0.001-0.005 \mathrm{gm}^{-3}$ ), with particles of mean diameter $6-7 \mu \mathrm{m}$. We interpret these conditions as hazy sub-cloud air, and according to the work of Vidaurre and Hallett (2009), we expect that droplet splashing should not affect the observations. Indeed, setting the "probably clear" $\rho_{\mathrm{L}}$ threshold as low as $0.002 \mathrm{gm}^{-3}$ revealed very little sensitivity in $N_{\mathrm{C}}$. We are thus highly confident that the average values of $N_{\mathrm{U}} \simeq 383 \mathrm{~cm}^{-3}$ below cloud base were indeed reliable for profile 4 .

\section{Discussion}

\subsection{Summary of arguments presented in this paper}

Downey et al. (1990) argued that long-range transport of aerosol from the Australian continent was responsible for cases of high $\mathrm{CN}$ concentrations at Macquarie Island, but it seems that a direct hit on an urban center was required, and they reported high correlation with radon (a continental tracer) in these instances. We used $\mathrm{CO}$ and $\mathrm{BC}$ as continental/anthropogenic markers, and showed that they were very effective in identifying the pollution plume from Melbourne in HIPPO-4 RF07.

Of the four vertical profiles performed in HIPPO-4 RF06, the one with the most convincing signature of anthropogenic and/or continental influence was profile 2, where a clear correlation between $\mathrm{CO}$ and $\mathrm{BC}$ was observed, possibly in several layers. The strongest signature was found between 4000 and $5000 \mathrm{ma}$ a.s.l., but even here there was no correlation to the sub-micron particle number concentration $N_{\mathrm{U}}$. Better correlation between the three values was identified at 1500 ma.s.l., where peak $N_{\mathrm{U}}$ values were over $100 \mathrm{~cm}^{-3}$, and back trajectories clearly suggest a terrestrial pollution source. In the boundary layer clouds sampled in profile 2, mean cloud droplet number concentrations were about $77 \mathrm{~cm}^{-3}$, which is not particularly unusual for the remote SO.

For profiles 3 and 4 we have argued that the most likely signature of anthropogenic and/or continental influence was at 3000-4000 ma.s.1., which was well above and decoupled from the boundary layer by a layer of clean air. Furthermore, $N_{\mathrm{U}}$ at those levels (about $80 \mathrm{~cm}^{-3}$ ) was insignificant in comparison to values within the boundary layer (nearly $400 \mathrm{~cm}^{-3}$ ). The trajectories that arrived in the boundary layer for profiles 3 and 4 show much weaker evidence for anthropogenic and/or continental influence, and were not coincidental with a trajectory from any industrial/urban centers. Yet the $N_{\mathrm{C}}$ and $N_{\mathrm{U}}$ values in profile 4 were about twice those of profile 2 , and up to four times the values for profile 1 . The very small increase in $\mathrm{CO}$ in the boundary layer may equally suggest a highly diluted anthropogenic signature or a natural maritime source, but in any case it is not nearly of sufficient magnitude to explain the $N_{\mathrm{U}}$ values. The microphysical results for profile 3 were similar, but we have somewhat less confidence in the UHSAS concentrations due to the potential for artifacts due to splashing droplets.

While $N_{\mathrm{C}}$ values of $150-300 \mathrm{~cm}^{-3}$ are by no means exceptional in a global context, they are unexpected for the pristine maritime environment of the SO, especially during wintertime when ocean productivity is lowest. If the hypothesis that such values were predominantly caused by longrange transport of continental pollutants can be rejected, as we argue in this paper, then we are left with the conclusion that the elevated particle concentration observed by the UHSAS, which probably includes most of the CCN, was produced locally. While alternative sources for the $\mathrm{CCN}$ cannot be completely ruled out without compositional analysis of the aerosol, we showed through modal decomposition of the UHSAS PSD for profile 4 that the mode representing primary marine aerosol, which is dominated by SSA, to be the main contributor to the aerosol population. We thus consider sea spray aerosol to be the best candidate to explain the elevated aerosol concentrations, and indeed there are many studies that suggest that SSA can dominate the marine boundary layer CCN population (e.g. Clarke et al., 2006; Murphy et al., 1998).

\subsection{General discussion of results}

Our conclusions contrast with the findings of Blot et al. (2013), which suggest that wind speed was not a factor in controlling SSA concentrations in the VOCALS campaign, and other authors (Bates et al., 1998; Covert et al., 1998; Berg et al., 1998) have also reported poor correlations of SSA concentrations with wind speed. However, the low-level wind speeds of $25-35 \mathrm{~m} \mathrm{~s}^{-1}$ encountered during profiles 3 and 4 was extreme, and well outside the ranges reported by Blot et al. (2013). Because the background aerosol concentrations were so low in this region, the additional SSA production would have had a significant impact on overall $\mathrm{CCN}$ as well as $N_{\mathrm{C}}$.

This result is of interest in discussions of the cloud structure and radiation bias over the SO. Gale force winds, such as those encountered in HIPPO-4 RF06, occur regularly over the SO; weather station data from Macquarie Island, which is nearby in the storm track region, had half hourly average surface wind speeds greater than this on about $15 \%$ of days between 2008 and 2011. Moreover, Korhonen et al. (2010) showed an increase in wind speed in the latitude band 
$50-65^{\circ} \mathrm{S}$ from 1980 to 2002 in reanalysis data, which has been verified observationally by Hande et al. (2012a). Over the same period, modeled $\mathrm{CCN}$ concentrations increased by $19 \%$ on average, and they found that wind speed accounted for $48 \%$ of the variance and was the most important cause of the changes. The resultant negative radiative forcing in this latitudinal band was on the same order as the positive forcing due to greenhouse gases.

The CCN concentrations for the study of Korhonen et al. (2010) were derived from a global aerosol model which includes a wind speed dependent SSA parameterization. The basis for such parameterizations has been questioned by several authors, as discussed in this paper. Nevertheless, the hypothesis that SSA could be a factor in such a climate feedback mechanism is supported by the observations of HIPPO4 RF06. Targeted observations are clearly needed to more convincingly address this hypothesis, which fits squarely within the stated priorities of the NSF Advisory Committee for Geosciences (2014).

\section{Conclusions}

In this paper we have presented thermodynamic, microphysical and atmospheric chemistry observations from vertical profiles performed during HIPPO-4 RF06. Large variation in microphysical characteristics of the boundary layer clouds and the aerosol concentration were found, and in particular the CDP cloud droplet number concentration $N_{\mathrm{C}}$ and UHSAS aerosol concentration $N_{\mathrm{U}}$ were substantially higher (by a factor of two to five) than expected for the southernmost profiles. At these latitudes the wind speeds were the most extreme, at $25-35 \mathrm{~m} \mathrm{~s}^{-1}$ at very low altitudes (about 167 ma.s.1.). We were unable to attribute these observations to continental and/or anthropogenic sources through the analysis of the atmospheric chemistry data and back trajectories, although there were indications of weak impacts at much higher altitudes in the profiles. We conclude that these observations are consistent with the local production of sea spray aerosol due to high winds in the southernmost regions of the flight. In order to reduce ambiguities such as those discussed in this paper, we strongly recommend the inclusion of aerosol chemical composition measurements for future cloud physics observational missions over the Southern Ocean.

Acknowledgements. This research was funded by ARC linkage grant LP120100115 and relies on data sets produced for the HIPPO deployments, and made available to the community by the National Center for Atmospheric Research's Earth Observing Laboratory. The National Center for Atmospheric Research is sponsored by the National Science Foundation. This paper has benefited from the thoughtful comments of three anonymous reviewers.

Edited by: M. Petters

\section{References}

Bates, T. S., Kapustin, V. N., Quinn, P. K., Covert, D. S., Coffman, D. J., Mari, C., Durkee, P. A., De Bruyn, W. J., and Saltzman, E. S.: Processes controlling the distribution of aerosol particles in the lower marine boundary layer during the First Aerosol Characterization Experiment (ACE 1), J. Geophys. Res.-Atmos., 103, 16369-16383, 1998.

Baumgardner, D. and Korolev, A.: Airspeed corrections for optical array probe sample volumes, J. Atmos. Ocean. Tech., 14, 12241229, 1997.

Bennartz, R.: Global assessment of marine boundary layer cloud droplet number concentration from satellite, J. Geophys. Res.Atmos., 112, D02201, doi:10.1029/2006JD007547, 2007.

Berg, O. H., Swietlicki, E., and Krejci, R.: Hygroscopic growth of aerosol particles in the marine boundary layer over the $\mathrm{Pa}$ cific and Southern Oceans during the First Aerosol Characterization Experiment (ACE 1), J. Geophys. Res.-Atmos., 103, 1653516545, 1998.

Blot, R., Clarke, A. D., Freitag, S., Kapustin, V., Howell, S. G., Jensen, J. B., Shank, L. M., McNaughton, C. S., and Brekhovskikh, V.: Ultrafine sea spray aerosol over the southeastern Pacific: open-ocean contributions to marine boundary layer CCN, Atmos. Chem. Phys., 13, 7263-7278, doi:10.5194/acp-137263-2013, 2013.

Boers, R. and Krummel, P. B.: Microphysical properties of boundary layer clouds over the Southern Ocean during ACE 1, J. Geophys. Res.-Atmos., 103, 16651-16663, 1998.

Boers, R., Jensen, J., Krummel, P., and Gerber, H.: Microphysical and short-wave radiative structure of wintertime stratocumulus clouds over the Southern Ocean, Q. J. Roy. Meteor. Soc., 122, 1307-1339, 1996.

Boers, R., Jensen, J., and Krummel, P.: Microphysical and shortwave radiative structure of stratocumulus clouds over the Southern Ocean: summer results and seasonal differences, Q. J. Roy. Meteor. Soc., 124, 151-168, 1998.

Boutle, I. A., Abel, S. J., Hill, P. G., and Morcrette, C. J.: Spatial variability of liquid cloud and rain: observations and microphysical effects, Q. J. Roy. Meteor. Soc., 140, 583-594, doi:10.1002/qj.2140, 2014.

Cai, Y., Montague, D. C., Mooiweer-Bryan, W., and Deshler, T.: Performance characteristics of the ultra high sensitivity aerosol spectrometer for particles between 55 and $800 \mathrm{~nm}$ : laboratory and field studies, J. Aerosol Sci., 39, 759-769, 2008.

Charlson, R. J., Lovelock, J. E., Andreae, M. O., and Warren, S. G.: Oceanic phytoplankton, atmospheric sulphur, cloud albedo and climate, Nature, 326, 655-661, 1987.

Chubb, T. H., Jensen, J. B., Siems, S. T., and Manton, M. J.: In situ observations of supercooled liquid clouds over the Southern Ocean during the HIAPER Pole-to-Pole Observation campaigns, Geophys. Res. Lett., 40, 5280-5285, 2013.

Clarke, A. D., Owens, S. R., and Zhou, J.: An ultrafine sea-salt flux from breaking waves: implications for cloud condensation nuclei in the remote marine atmosphere, J. Geophys. Res.-Atmos., 111, D06202, doi:10.1029/2005JD006565, 2006.

Covert, D. S., Gras, J. L., Wiedensohler, A., and Stratmann, F.: Comparison of directly measured $\mathrm{CCN}$ with $\mathrm{CCN}$ modeled from the number-size distribution in the marine boundary layer during ACE 1 at Cape Grim, Tasmania, J. Geophys. Res.-Atmos., 103, 16597-16608, 1998. 
Day, J.: Production of droplets and salt nuclei by the bursting of air-bubble films, Q. J. Roy. Meteor. Soc., 90, 72-78, 1964.

De Deckker, P., Norman, M., Goodwin, I. D., Wain, A., and Gingele, F. X.: Lead isotopic evidence for an Australian source of aeolian dust to Antarctica at times over the last 170000 years, Palaeogeography, Palaeoclimatology, Palaeoecology, 285, 205223, doi:10.1016/j.palaeo.2009.11.013, 2010.

de Leeuw, G., Andreas, E. L., Anguelova, M. D., Fairall, C., Lewis, E. R., O'Dowd, C., Schulz, M., and Schwartz, S. E.: Production flux of sea spray aerosol, Rev. Geophys., 49, RG2001, doi:10.1029/2010RG000349, 2011.

Downey, A., Jasper, J., Gras, J., and Whittlestone, S.: Lower tropospheric transport over the Southern Ocean, J. Atmos. Chem., 11, 43-68, 1990.

Draxler, R. and Hess, G.: An overview of the HYSPLIT_4 modelling system for trajectories, dispersion and deposition, Aust. Meteorol. Mag., 47, 295-308, 1998.

Gerbig, C., Schmitgen, S., Kley, D., Volz-Thomas, A., Dewey, K., and Haks, D.: An improved fast-response vacuum-UV resonance fluorescence CO instrument, J. Geophys. Res.-Atmos., 104, 1699-1704, 1999.

Grosvenor, D. P. and Wood, R.: The effect of solar zenith angle on MODIS cloud optical and microphysical retrievals within marine liquid water clouds, Atmos. Chem. Phys., 14, 7291-7321, doi:10.5194/acp-14-7291-2014, 2014.

Hande, L., Siems, S., and Manton, M.: Observed trends in wind speed over the Southern Ocean, Geophys. Res. Lett., 39, L11802, doi:10.1029/2012GL051734, 2012a.

Hande, L., Siems, S., Manton, M., and Belusic, D.: Observations of wind shear over the Southern Ocean, J. Geophys. Res.-Atmos., 117, D12206, doi:10.1029/2012JD017488, 2012b.

Hansen, J. E. and Travis, L. D.: Light scattering in planetary atmospheres, Space Sci. Rev., 16, 527-610, 1974.

Huang, Y., Franklin, C. N., Siems, S. T., Manton, M. J., Chubb, T., Lock, A., Alexander, S., and Klekociuk, A.: Evaluation of boundary-layer cloud forecasts over the Southern Ocean in a limited-area numerical weather prediction system using in situ, space-borne and ground-based observations, Q. J. Roy. Meteor. Soc., 141, 2259-2276, doi:10.1002/qj.2519, 2015.

Kassianov, E., Berg, L. K., Pekour, M., Barnard, J., Chand, D., Flynn, C., Ovchinnikov, M., Sedlacek, A., Schmid, B., Shilling, J., and Tomlinson, J.: Airborne aerosol in situ measurements during TCAP: A closure study of total scattering, Atmosphere, 6, 1069-1101, doi:10.3390/atmos6081069, 2015.

King, W., Parkin, D., and Handsworth, R.: A hot-wire liquid water device having fully calculable response characteristics, J. Appl. Meteorol., 17, 1809-1813, 1978.

Korhonen, H., Carslaw, K. S., Forster, P. M., Mikkonen, S., Gordon, N. D., and Kokkola, H.: Aerosol climate feedback due to decadal increases in Southern Hemisphere wind speeds, Geophys. Res. Lett., 37, L02805, doi:10.1029/2009GL041320, 2010.

Lance, S., Brock, C. A., Rogers, D., and Gordon, J. A.: Water droplet calibration of the Cloud Droplet Probe (CDP) and inflight performance in liquid, ice and mixed-phase clouds during ARCPAC, Atmos. Meas. Tech., 3, 1683-1706, doi:10.5194/amt3-1683-2010, 2010.

Lewis, E. R. and Schwartz, S. E.: Sea salt aerosol production: mechanisms, methods, measurements, and models - a critical review, EOS T. Am. Geophys. Union, 152, 101-127, availabe at: http://onlinelibrary.wiley.com/book/10.1029/GM152 (last access: 25 January 2016), 2004.

Marks, R.: Preliminary investigations on the influence of rain on the production, concentration, and vertical distribution of sea salt aerosol, J. Geophys. Res.-Oceans, 95, 22299-22304, 1990.

Martin, J. H.: Glacial-interglacial $\mathrm{CO}_{2}$ change: the Iron Hypothesis, Paleoceanography, 5, 1-13, 1990.

Meehl, G. A., Covey, C., Taylor, K. E., Delworth, T., Stouffer, R. J., Latif, M., McAvaney, B., and Mitchell, J. F.: The WCRP CMIP3 multimodel dataset: a new era in climate change research, B. Am. Meteorol. Soc., 88, 1383-1394, 2007.

Modini, R. L., Frossard, A. A., Ahlm, L., Russell, L. M., Corrigan, C. E., Roberts, G. C., Hawkins, L. N., Schroder, J. C., Bertram, A. K., Zhao, R., Lee, A. K. Y., Abbatt, J. P. D., Lin, J., Nenes, A., Wang, Z., Wonaschütz, A., Sorooshian, A., Noone, K. J., Jonsson, H., Seinfeld, J. H., Toom-Sauntry, D., Macdonald, A. M., and Leaitch, W. R.: Primary marine aerosol-cloud interactions off the coast of California, J. Geophys. Res.-Atmos., 120, 42824303, doi:10.1002/2014JD022963, 2015.

Murphy, D. M., Anderson, J. R., Quinn, P. K., McInnes, L. M., Brechtel, F. J., Kreidenweis, S. M., Middlebrook, A. M., Pósfai, M., Thomson, D. S., and Buseck, P. R.: Influence of seasalt on aerosol radiative properties in the Southern Ocean marine boundary layer, Nature, 392, 62-65, doi:10.1038/32138, 1998.

Nakajima, T. and King, M. D.: Determination of the optical thickness and effective particle radius of clouds from reflected solar radiation measurements. Part I: Theory, J. Atmos. Sci., 47, 18781893, 1990.

Nilsson, E., Rannik, Ü., Swietlicki, E., Leck, C., Aalto, P. P., Zhou, J., and Norman, M.: Turbulent aerosol fluxes over the Arctic Ocean: 2. Wind-driven sources from the sea, J. Geophys. Res.Atmos., 106, 32139-32154, 2001.

NSF Advisory Committee for Geosciences: Dynamic Earth: GEO Imperatives and Frontiers 2015-2020, Tech. rep., National Science Foundation, Arlington, VA 22230, USA, 2014.

O'Dowd, C. D. and Smith, M. H.: Physicochemical properties of aerosols over the northeast Atlantic: evidence for wind-speedrelated submicron sea-salt aerosol production, J. Geophys. Res.Atmos., 98, 1137-1149, 1993.

O’Loingsigh, T., McTainsh, G., Tews, E., Strong, C., Leys, J., Shinkfield, P., and Tapper, N.: The Dust Storm Index (DSI): a method for monitoring broadscale wind erosion using meteorological records, Aeolian Res., 12, 29-40, 2014.

Pruppacher, H. R., Klett, J. D., and Wang, P. K.: Microphysics of clouds and precipitation, Kluwer Academic Publishers, 3300 AA Dordrecht, the Netherlands, 1998.

Quinn, P. and Bates, T.: The case against climate regulation via oceanic phytoplankton sulphur emissions, Nature, 480, 51-56, 2011.

Revel-Rolland, M., De Deckker, P., Delmonte, B., Hesse, P., Magee, J., Basile-Doelsch, I., Grousset, F., and Bosch, D.: Eastern Australia: a possible source of dust in East Antarctica interglacial ice, Earth Planet. Sc. Lett., 249, 1-13, 2006.

Romashkin, P.: NCAR GV (HIAPER) Low Rate (LRT - $1 \mathrm{sps}$ ) Navigation, State Parameter, and Microphysics Flight-Level Data, Tech. rep., UCAR/NCAR - Earth Observing Laboratory, Boulder, CO 80307, USA, available at: http://www.eol.ucar.edu/ system/files/PM_notes_HIPPO-4_-5.doc, (last access: $31 \mathrm{Au}-$ gust 2015), 2012. 
Rosenfeld, D. and Gutman, G.: Retrieving microphysical properties near the tops of potential rain clouds by multispectral analysis of AVHRR data, Atmos. Res., 34, 259-283, 1994.

Russell, L. M., Lenschow, D. H., Laursen, K. K., Krummel, P. B., Siems, S. T., Bandy, A. R., Thornton, D. C., and Bates, T. S.: Bidirectional mixing in an ACE 1 marine boundary layer overlain by a second turbulent layer, J. Geophys. Res.-Atmos., 103, 16411-16432, 1998.

Salomonson, V. V., Barnes, W., Maymon, P. W., Montgomery, H. E., and Ostrow, H.: MODIS: advanced facility instrument for studies of the Earth as a system, IEEE T. Geosci. Remote, 27, 145-153, 1989.

Schwarz, J. P., Gao, R. S., Fahey, D. W., Thomson, D. S., Watts, L. A., Wilson, J. C., Reeves, J. M., Darbeheshti, M., Baumgardner, D. G., Kok, G. L., Chung, S. H., Schulz, M., Hendricks, J., Lauer, A., Kärcher, B., Slowik, J. G., Rosenlof, K. H., Thompson, T. L., Langford, A. O., Loewenstein, M., and Aikin, K. C.: Single-particle measurements of midlatitude black carbon and light-scattering aerosols from the boundary layer to the lower stratosphere, J. Geophys. Res.-Atmos., 111, D16207, doi:10.1029/2006JD007076, 2006.

Trenberth, K. E. and Fasullo, J. T.: Simulation of present-day and twenty-first-century energy budgets of the southern oceans, J. Climate, 23, 440-454, 2010.

Vidaurre, G. and Hallett, J.: Particle impact and breakup in aircraft measurement, J. Atmos. Ocean. Tech., 26, 972-983, 2009.

Wofsy, S.: HIAPER Pole-to-Pole Observations (HIPPO): finegrained, global-scale measurements of climatically important atmospheric gases and aerosols, Philos. T. R. Soc. A, 369, 20732086, 2011.
Wofsy, S. C., Daube, B. C., Jimenez, R., Kort, E., Pittman, J. V., Park, S., Commane, R., Xiang, B., Santoni, G., Jacob, D., Fisher, J., Pickett-Heaps, C., Wang, H., Wecht, K., Wang, Q.-Q., Stephens, B. B., Shertz, S., Watt, A. S., Romashkin, P., Campos, T., Haggerty, J., Cooper, W. A., Rogers, D., Beaton, S., Hendershot, R., Elkins, J. W., Fahey, D. W., Gao, R. S., Moore, F., Montzka, S. A., Schwarz, J. P., Perring, A. E., Hurst, D., Miller, B. R., Sweeney, C., Oltmans, S., Nance, D., Hintsa, E., Dutton, G., Watts, L. A., Spackman, J. R., Rosenlof, K. H., Ray, E. A., Hall, B., Zondlo, M. A., Diao, M., Keeling, R., Bent, J., Atlas, E. L., Lueb, R., and Mahoney, M. J.: HIPPO Merged 10second Meteorology, Atmospheric Chemistry, and Aerosol Data (R_20121129), Tech. rep., Carbon Dioxide Information Analysis Center, Oak Ridge National Laboratory, Oak Ridge, Tennessee, USA, doi:10.3334/CDIAC/hippo_010, 2012.

Wood, R. and Field, P. R.: The distribution of cloud horizontal sizes, J. Climate, 24, 4800-4816, 2011.

Woodcock, A. H.: Salt nuclei in marine air as a function of altitude and wind force, J. Meteorol., 10, 362-371, 1953.

Yum, S. S. and Hudson, J. G.: Wintertime/summertime contrasts of cloud condensation nuclei and cloud microphysics over the Southern Ocean, J. Geophys. Res.-Atmos., 109, D06204, doi:10.1029/2003JD003864, 2004. 